\title{
A CONSTRUÇÃO HISTÓRICA DO DIREITO DO TRABALHO COMO RESISTÊNCIA À APLICAÇÃO DO PÓS-POSITIVISMO
}

\author{
Dissertação de Mestrado \\ Orientador: Professor Doutor Jorge Luiz Souto Maior
}

UNIVERSIDADE DE SÃO PAULO

FACULDADE DE DIREITO

2015 
CLAUDIA URANO DE CARVALHO MACHADO

\section{A CONSTRUÇÃO HISTÓRICA DO DIREITO DO TRABALHO COMO RESISTÊNCIA À APLICAÇÃO DO PÓS-POSITIVISMO}

Dissertação apresentada à Banca Examinadora do Programa de Pós-Graduação em Direito, da Faculdade de Direito da Universidade de São Paulo, como exigência parcial para obtenção do título de Mestre em Direito, na área de concentração Direito do Trabalho e da Seguridade Social, sob a orientação do Professor Doutor Jorge Luiz Souto Maior.

UNIVERSIDADE DE SÃO PAULO

FACULDADE DE DIREITO

2015 
Autorizo a reprodução e divulgação total ou parcial deste trabalho, por qualquer meio convencional ou eletrônico, para fins de estudo e pesquisa, desde que citada a fonte.

Catalogação na publicação

Faculdade de Direito da Universidade de São Paulo

MACHADO, Claudia Urano de Carvalho. A construção histórica do Direito do Trabalho como resistência à aplicação do pós-positivismo (Dissertação de Mestrado) - São Paulo, 2015 .

$75 \mathrm{p}$.

Dissertação (Mestrado) - Departamento de Direito do Trabalho e Seguridade Social. Área de concentração: Direito do Trabalho.

CDD 
Nome: MACHADO, Claudia Urano de Carvalho

Título: A construção histórica do Direito do Trabalho como resistência à aplicação do Póspositivismo.

Dissertação apresentada ao Departamento de Direito do Trabalho e da Seguridade Social da Universidade de São Paulo como requisito parcial para a obtenção do título de Mestra em Direito do Trabalho e da Seguridade Social.

Aprovada em:

\section{BANCA EXAMINADORA}

Prof.

Instituição:

Julgamento:

Assinatura:

Prof.

Instituição:

Julgamento:

Assinatura:

Prof.

Instituição:

Julgamento:

Assinatura: 


\section{AGRADECIMENTO}

Sem o contato com os textos e palestras do meu Orientador, Jorge Luiz Souto Maior, quando eu ainda era uma estudante de Direito em Franca, na UNESP, meu amor pelo Direito do Trabalho, por certo, não seria o mesmo. A ele devo a área que segui. Grata sou por instigar em mim e, por certo, em cada um de seus alunos, o senso crítico quando se estuda Direito do Trabalho.

Agradeço ao Professor Orione por toda a compreensão durante o período do mestrado, principalmente, durante a gravidez.

Agradeço, também, ao meu pai, Marcos Machado, cujas palavras ainda ecoam na minha memória: "tem que fazer mestrado!", ciente de que nosso aperfeiçoamento não termina na Graduação.

À minha mãe, Analba Machado, primeira a despertar em mim a paixão pelo magistério.

Ao meu irmão Guilherme Machado, pelo exemplo de excelência nos estudos.

Agradeço, principalmente, à minha irmã e comadre, Carolina Machado, que dedicou seus cuidados ao meu pequeno João Henrique, na etapa final desse trabalho. Seu auxílio foi imprescindível.

À Dra. Danielle Viana Soares, juíza de quem sou assistente na Justiça do Trabalho de São Paulo, pelo apoio e compreensão.

Ao Professor e amigo Marcos Scalercio, por me ouvir inúmeras vezes falando do tema, com a receptividade de sempre.

À amiga de todas as horas, Mirian Bonomi, pela ajuda na revisão da língua estrangeira e, também, em outra frente, ter criado nosso grupo de mães, que tanto me ensina, acalma e apóia. Obrigada, meninas. 
À Josy Simões, por ter dormido com meu pequeno João Henrique na última semana antes da entrega deste trabalho, acalentando-os nas ainda constantes mamadas da madrugada, para que eu pudesse realizar os ajustes finais

Como poderei incorrer no erro (imperdoável!) de esquecer qualquer deles, o que não diminuiria a importância que tiveram no meu aprofundamento acerca da história do Direito do Trabalho, consigno, aqui, meus agradecimentos a todos e a cada um dos membros do Grupo de Pesquisa Trabalho e Capital..

Ao meu marido, Celso Henrique, por me tranquilizar quando muitas vezes duvidei da minha capacidade. Ele e o João Henrique são a razão da minha vida.

Finalmente, registro meu agradecimento a todos aqueles de cujo convívio precisei abdicar durante a redação deste trabalho, mas com o coração tranquilo de que, se compreenderam, é porque sabem da importância dele para mim e, com certeza, hoje compartilham da minha felicidade em vê-lo entregue. 
Dedico esse trabalho a todas as mulheres, trabalhadoras e mães. Porque elas, como ninguém, compreendem o quanto a sociedade capitalista exige de nós, como força de trabalho e, principalmente, como as únicas responsáveis pelo cuidado com nossos filhos; somente elas conhecem, empiricamente, a angústia gerada por não poder realizar nenhuma dessas atividades a contento, talvez por uma exigência de excelência incutida em nós também por obra do mesmo sistema capitalista. Jamais duvidemos da força dessas mulheres.

Como não poderia deixar de ser, dedico esse trabalho, sobretudo, ao meu filho João Henrique, que nos brindou com seu nascimento próximo à conclusão do Mestrado, e me mostrou a força que tenho como mulher, mãe, trabalhadora e, ainda, pós-graduanda. 
Não se trata apenas de saber que futuro nos espera, mas o que o futuro espera de nós. E não há neutralidade possível. Ou ajudamos a demolir o direito, ou lutamos para reconstruí-lo; ou nos curvamos à nova ordem, ou semeamos alguma desordem no caos.

- Marcio Tulio Viana 
MACHADO, Claudia Urano de Carvalho. A construção histórica do Direito do Trabalho como resistência à aplicação do pós-positivismo. 2015. 75.p. Grau de Mestrado Faculdade de Direito, Universidade de São Paulo, São Paulo, 2015.

\section{RESUMO}

O advento da teoria pós-positivista de Robert Alexy teve seus efeitos sentidos no Direito do Trabalho, principalmente por passar a ser constantemente mencionada em decisões trabalhistas. O presente trabalho se propõe, então, a dois objetivos centrais: a partir da análise da principal obra de Robert Alexy, Teoria dos Direitos Fundamentais, em cotejo com a jurisprudência trabalhista, demonstrar que nessas decisões não há, de fato, a aplicação da teoria pós-positivista, tal qual construída pelo jurista alemão e, posteriormente, que, ainda que fosse aplicada corretamente, ela própria é de todo incompatível com o Direito do Trabalho, em virtude da construção histórica deste ramo.

Palavras-chave: Robert Alexy - Pós-positivismo - Direitos Fundamentais - Ponderação. História do Direito do Trabalho 


\begin{abstract}
The advent of the post-positivist theory of Robert Alexy had its consequences on Labor Law, especially for being often mentioned on Labor Court decisions. Thus, this dissertation focuses on two main objectives: to demonstrate, based on the analysis of the main work of Robert Alexy - Theory of Fundamental Rights - in confrontation with some Labour Court decisions, that such decisions do not, in fact, apply the post-positivist theory as it was formulated by the German jurist; and, moreover, even if it were to be applied accordingly, this theory would still be incompatible with Labor Law, due to the historical construction of this area.
\end{abstract}

Keywords: Robert Alexy - Post-positivism - Fundamental Rights - Balancing - History of Labor Law 


\section{ÍNDICE}

INTRODUÇÃO

1. O Pós-positivismo para Robert Alexy 16

1.1. A distinção entre princípios e regras 16

1.2. A ponderação de princípios e o princípio da proporcionalidade 21

1.3. Direitos sociais e ponderação 29

2 - O Pós-positivismo de Alexy e a jurisprudência trabalhista 38

3 - Inaplicabilidade da teoria de Alexy ao Direito do Trabalho 56

CONCLUSÃO 68 


\title{
INTRODUÇÃO
}

\author{
"A constatação da natureza ideológica de \\ um conceito não nos dispensa, de forma \\ alguma, da obrigação de estudar a \\ realidade objetiva, quer dizer, a realidade \\ existente no mundo exterior e não apenas \\ na consciência."
}

- Evgeny Pachukanis

É na aplicação do Direito que podemos observar com mais nitidez as consequências desta ou daquela teoria jurídica, atuando como força viva. Por meio do resultado prático procedido na vida daqueles que se socorrem do Poder Judiciário temos os elementos necessários para a análise do que, até então, era apenas objeto de elucubrações no interior da academia.

Assim aconteceu com o que, no presente trabalho, limitar-nos-emos a chamar de Pós-positivismo. Foi por meio da observância da constante menção de sua atuação na prática jurisprudencial que fomos despertados para o interesse de analisá-la criticamente, desde suas premissas básicas, partindo da análise do autor mais mencionado nessas decisões, Robert Alexy.

A partir da primeira década do ano 2000, não por acaso logo após a publicação da Teoria Geral dos Direitos Fundamentais no Brasil, principal obra de Robert Alexy, sua utilização passou a ser constatada numa série de julgados trabalhistas e seus efeitos sentidos nos estudos envolvendo Direito do Trabalho e é por isso que nos deteremos à análise desta obra.

Assim, trazendo como grande novidade a força normativa atribuída aos princípios, o objetivo propugnado pela doutrina pós-positivista aqui tratada está na inserção de valores éticos e morais no próprio Direito, permitindo, por conseguinte, que o 
julgador utilize-se de juízos de proporcionalidade e razoabilidade na busca da decisão tida como mais justa no caso concreto.

Para os adeptos dessa teoria a respeito da Constituição, era preciso abandonar o positivismo clássico, que conferia ao legislador o papel central e reservava ao juiz mero papel secundário de apenas declarar o conteúdo das normas jurídicas.

Supera-se, assim, a técnica da subsunção do fato à norma, esta última incapaz, por si só, de prever todos os fatos da vida e cuja aplicação indiscriminada havia legitimado barbáries como aquelas ocorridas no período nazista. Alguns parâmetros morais de justiça precisavam ingressar no direito, vez que os critérios formais de validade não foram suficientes.

\begin{abstract}
Sem embargo da resistência filosófica de outros movimentos influentes nas primeiras décadas do século XX, a decadência do positivismo é emblematicamente associada à derrota do fascismo na Itália e do nazismo na Alemanha. Esses movimentos políticos e militares ascenderam ao poder dentro do quadro de legalidade vigente, e promoveram a barbárie em nome da lei. Os principais acusados de Nuremberg invocaram o cumprimento da lei e a obediência a ordens emanadas da autoridade competente Ao fim da II Guerra Mundial a ideia de um ordenamento indiferente a valores éticos e da lei como uma estrutura meramente formal, uma embalagem para qualquer produto, já não tinha mais aceitação no pensamento esclarecido. ${ }^{1}$
\end{abstract}

Os princípios, também, deixam de ter caráter meramente supletivo para os casos de lacunas na lei ou interpretativo das normas jurídicas, passando a ostentar plena força normativa.

Dado o seu caráter aberto, mais de um princípio pode incidir sobre uma determinada situação concreta. Nesses casos mais complexos, passa-se à adoção da técnica da ponderação de princípios, através de um sopesamento, a fim de se chegar à solução do caso concreto, sem se desfazer de nenhum desses interesses, mas apenas afastando um deles naquele específico caso.

Assim, na perspectiva do Pós-positivismo, não basta apenas atribuir-se ao juiz um poder discricionário para a definição de direitos e obrigações jurídicos quando se

\footnotetext{
${ }^{1}$ BARROSO, Luís Roberto e BARCELLOS,Ana Paula de. O começo da história: a nova interpretação constitucional e o papel dos princípios no direito brasileiro. In SILVA, Virgilio Afonso da. (Org.) Interpretação constitucional. São Paulo: Melhoramentos, 2007. pp.271-316. p.278.
} 
deparar com uma questão de direito de solução mais complexa; há, então, um esforço teórico para a produção de regras que balizem a atividade decisória judicial na análise dessas pretensões trazidas a Juízo.

O Pós-positivismo, segundo Luís Roberto Barroso,

\begin{abstract}
é a designação provisória e genérica de um ideário difuso, no qual se incluem a definição das relações entre valores, princípios e regras, aspectos da chamada nova hermenêutica constitucional e a teoria dos direitos fundamentais, edificado sobre o fundamento da dignidade humana. A valorização dos princípios, sua incorporação, implícita ou explícita, pelos textos constitucionais e o reconhecimento pela ordem jurídica de sua normatização fazem parte desse ambiente de reaproximação entre direito e ética ${ }^{2}$.
\end{abstract}

Assim, se de início uma teoria envolvendo a força normativa dos princípios pareceu-nos deveras interessante, talvez premidos pela expectativa de que veríamos a atuação efetiva dos princípios trabalhistas da proteção, da justiça social e da solidariedade, logo fomos surpreendidos pela ponderação desses princípios, procedida pelo Poder Judiciário, com outros de natureza meramente individual, não raro fazendo com que estes últimos prevalecessem, o que nos mostrou quão urgente se fazia esmiuçar essa nova teoria, para garantirmos, em última análise, a própria sobrevivência e aplicação do Direito do Trabalho como um ramo autônomo do Direito, com vistas à melhoria constante da condição social do ser humano trabalhador.

Não bastava, então, apenas rechaçar sua aplicabilidade nas sendas do Direito do Trabalho, era necessário fornecer os parâmetros para uma tal conclusão, através da análise minuciosa da obra que fundamenta a maior parte dos julgados envolvendo o Póspositivismo. E é assim que procedemos.

Partiremos da distinção primordial à Teoria dos Direitos Fundamentais de Robert Alexy, a diferenciação entre princípios e regras, analisaremos mais detidamente a ponderação por meio de um juízo de proporcionalidade, inclusive acerca dos direito sociais, e, assim, chegaremos à sua utilização pelos julgados trabalhistas.

A partir daí, buscaremos demonstrar como vem se dando sua aplicação nesta seara para, ao final, procedermos à análise crítica, a fim de demonstrar que, mesmo se aplicada de maneira adequada, não teria incidência no Direito do Trabalho, seja porque os

\footnotetext{
${ }^{2}$ Ibidem, p. 279.
} 
aparentes conflitos de valores e casos concretos se solucionam pela aplicação dos princípios do Direito do Trabalho, seja porque a teoria em questão teria exatamente o problema de gerar nebulosidades teóricas onde, de fato, não deveria haver. 


\title{
CAPÍTULO 1
}

\section{O PÓS-POSITIVISMO PARA ROBERT ALEXY}

\author{
"Mais princípios que regras; mais \\ ponderação que subsunção; mais \\ Constituição que lei; mais juiz que \\ legislador."
}

- Pietro Sanchís

O Pós-positivismo é uma doutrina ampla, trazendo uma grande diversidade de autores que a ele se dedicam, não havendo como falar simplesmente em Pós-positivismo lato sensu. Os autores divergem em muitos pontos, ainda que se digam todos póspositivistas.

Desse modo, em que pese nos refiramos, no presente trabalho, simplesmente ao "Pós-positivismo", estudaremos, mais detidamente o Pós-positivismo de Robert Alexy, uma vez que é a este autor que a maior gama de julgados trabalhistas se referem.

\subsection{A distinção entre princípios e regras}

Os estudos acerca da Teoria Geral dos Direitos Fundamentais de Robert Alexy partem da diferenciação entre princípios e regras, "uma das colunas-mestras do edifício da teoria do direitos fundamentais" ${ }^{3}$.

Segundo Robert Alexy, esta é a principal diferenciação a se proceder quando da análise do conceito de norma de direito fundamental, constituindo a base da teoria da fundamentação no âmbito específico dos direitos fundamentais, de modo que “sem ela não pode haver nem uma teoria adequada sobre as restrições a direitos

\footnotetext{
${ }^{3}$ ALEXY, Robert. Teoria dos direitos fundamentais. Tradução de Virgílio Afonso da Silva. São Paulo: Malheiros, 2008, p.85.
} 
fundamentais, nem uma doutrina satisfatória sobre colisões, nem uma teoria suficiente sobre o papel dos direitos fundamentais no sistema jurídico." ${ }^{4}$

Reconhece, todavia, que a distinção entre regras e princípios não é nova, mas, a despeito de sua longevidade e de sua frequente utilização, ainda lhe falta clareza e sobra polêmica ${ }^{5}$.

Segundo o autor alemão, o importante papel desempenhado pela precisa diferenciação entre regras e princípios, embora não usualmente colocada nesses termos, é sentida em ocasiões tais em que se ressalta o caráter principiológico dos direitos fundamentais, o que se dá, por exemplo

$$
\begin{aligned}
& \text { quando se fala em valores, objetivos, fórmulas abreviadas ou regras } \\
& \text { sobre ônus argumentativo. Por outro lado, faz-se referência às } \\
& \text { normas de direitos fundamentais como regras quando se afirma que } \\
& \text { a Constituição deve ser levada a sério como lei, ou quando se aponta } \\
& \text { para a possibilidade de fundamentação dedutiva também no âmbito } \\
& \text { dos direitos fundamentais. }{ }^{6}
\end{aligned}
$$

Nesse sentido, adverte que faltava, ainda, uma distinção precisa entre esses conceitos e uma utilização sistemática dessa distinção, uma vez que as caracterizações supradescritas permaneciam, quase sempre, no nível de sugestões.

Assim, não só as regras são espécie do gênero maior consubstanciado pela norma jurídica, mas também os princípios, porquanto ambos são formulados com a ajuda de expressões deônticas fundamentais (mandamento, permissão e proibição).

Segundo Alexy, "princípios são, tanto quanto as regras, razões para juízos concretos de dever ser, ainda que de espécie muito diferente. A distinção entre regras e princípios é, portanto, uma distinção entre duas espécies de normas.",

Embora se refira a critérios outros para referida distinção, como o da generalidade, a determinabilidade dos casos de aplicação, a forma de seu surgimento, o caráter explícito do conteúdo axiológico, a importância que apresentam para a ordem jurídica, segundo Alexy, o critério que distingue, de forma precisa, essas duas espécies de normas é, sim, o da qualidade.

\footnotetext{
${ }^{4}$ Ibidem.

${ }^{5}$ Ibidem, p.87.

${ }^{6}$ Ibidem.

${ }^{7}$ Ibidem.
} 
Dessa forma, trata-se de uma distinção qualitativa, e não de grau, senão vejamos:

\begin{abstract}
O ponto decisivo na distinção entre regras e princípios é que princípios são normas que ordenam que algo seja realizado na maior medida possível dentro das possibilidades jurídicas e fáticas existentes. Princípios, por conseguinte, são mandamentos de otimização, que são caracterizados por poderem ser satisfeitos em graus variados e pelo fato de que a medida devida de sua satisfação não depende das possibilidades fáticas, mas também das possibilidades jurídicas. O âmbito das possibilidades jurídicas é determinado pelos princípios e regras colidentes ${ }^{8}$.
\end{abstract}

As regras, por sua vez,

são normas que são sempre satisfeitas ou não satisfeitas. Se uma regra vale, então, deve-se fazer exatamente aquilo que ela exige; nem mais, nem menos. Regras contêm, portanto, determinações no âmbito daquilo que é fática e juridicamente possível. ${ }^{9}$

A maior nitidez dessa distinção reside em casos de colisão de princípios e de conflitos de regras. Para Alexy,

Comum às colisões entre princípios e aos conflitos entre regras é o fato de que duas normas, se isoladamente aplicadas, levariam a resultados inconciliáveis entre si, ou seja, a dois juízos concretos de dever-ser jurídico contraditórios. E elas se distinguem pela forma de solução de conflitos. ${ }^{10}$

A solução de um conflito entre regras, assim, somente pode ser obtida se for incluída em uma delas uma cláusula de exceção que, então, dê por findo o conflito ou pela declaração de que uma dessas normas é inválida.

Recorrendo constantemente aos exemplos para melhor elucidar seus estudos, explica Alexy a primeira forma de solução - introdução de uma cláusula de exceção - por meio de um conflito entre as regras de proibição de sair da sala de aula antes que o sinal toque e o dever de deixar a sala se soar o alarme de incêndio.

Para ele, não obstante já tenha soado o alarme de incêndio, se o sinal ainda não houver tocado, tais regras conduziriam a juízos concretos inconciliáveis entre si,

\footnotetext{
${ }^{8}$ Ibidem, p.90.

${ }^{9}$ Ibidem, p.91

${ }^{10}$ Ibidem, p.92.
} 
porque contraditórios, concluindo, neste caso, que tal conflito haveria de ser solucionado pela inserção, na primeira, regra, de uma cláusula de exceção para a hipótese do alarme de incêndio. $^{11}$

Conforme supradeclinado, não sendo possível a inserção dessa cláusula, pelo menos uma das regras haverá de ser declarada inválida, sendo, assim, extirpada do ordenamento jurídico. Aqui, a questão é, primordialmente, sobre a validade, de modo que uma norma ou é válida ou não é, não sendo a validade jurídica um conceito graduável.

Para Alexy, "não importa a forma como sejam fundamentados, não é possível que dois juízos concretos de dever-ser contraditórios entre si sejam válidos." ${ }^{12}$

Como explicação da segunda maneira de solucionar um conflito de regras a declaração de nulidade/ invalidade de uma das normas, Alexy utiliza do seguinte exemplo:

\begin{abstract}
O Tribunal Constitucional Federal resolveu, [...] com base na norma sobre conflitos do art.31 da Constituição alemã (o direito federal tem prioridade sobre o direito estadual) [...] o conflito entre o § 22, 1, da ordenação sobre o horário de trabalho, de 1934 e 1938 (direito federal vigente na época da decisão), que, pela interpretação do tribunal, permitia a abertura de loja entre 7 e $19 \mathrm{~h}$ nos dias úteis, e o $\S 2^{\circ}$ da lei do Estado de Baden sobre o horário de funcionamento do comércio, de 1951, que, entre outras coisas, proibia a abertura de lojas após as $13 \mathrm{~h}$ nas quartas-feiras. As duas regras não poderiam valer ao mesmo tempo, caso contrário a abertura das lojas nas tardes de quartas-feiras seria tanto permitida quanto proibida. A possibilidade de considerar a cláusula da lei estadual como uma exceção ao direito federal estava excluída, em face do art.31 da Constituição. Nesse sentido, restou apenas a possibilidade de declaração de nulidade da norma de direito estadual. ${ }^{13}$
\end{abstract}

Na colisão entre princípios, contudo, as soluções são bem diferentes. Nesse caso, não haverá que se falar em cláusula de exceção ou mesmo na invalidade de um dos princípios colidentes, mas proceder-se-á ao que Alexy chamou de "sopesamento entre os interesses conflitantes." 14

\footnotetext{
${ }^{11}$ Ibidem, p.92.

${ }^{12}$ Ibidem.

${ }^{13}$ Ibidem, p. 93 .

${ }^{14}$ Ibidem, p.95.
} 
Diferentemente das regras, os princípios podem ser afastados por razões antagônicas, daí o caráter prima facie desses mesmos princípios. As regras, diferentemente, possuiriam conotação definitiva.

Ressalta, todavia, Alexy, que tal diferenciação não pode ser tida como constante e, assim, destacada como uma efetiva diferença entre os institutos em análise. Isso porque as próprias regras podem vir a apresentar o caráter prima facie que se atribuiu, inicialmente, apenas aos princípios.

Dessa forma, caso houvesse, num determinado caso concreto, a possibilidade de se estabelecer uma cláusula de exceção, perderia a regra o seu caráter de definitividade; naquelas em que não se admite a inserção desta cláusula, por sua vez, restaria vislumbrado, também nas regras, o caráter prima facie:

\begin{abstract}
Um princípio cede lugar quando, em determinado caso, é conferido um peso maior a outro princípio antagônico. Já uma regra não é superada pura e simplesmente quando se atribui, no caso concreto, um peso maior ao princípio contrário ao princípio que ostenta a regra. É necessário que sejam superados também aqueles princípios que estabelecem que as regras que tenham sido criadas pelas autoridades legitimadas para tanto devem ser seguidas, e que não se pode relativizar sem motivos uma prática estabelecida. Tais princípios devem ser denominados "princípios formais". Em um ordenamento jurídico, quanto mais peso se atribui aos princípios formais, tanto mais forte será o caráter prima facie de suas regras. Somente quando se deixa de atribuir algum peso a esse tipo de princípios - o que teria como consequência o fim da validade das regras enquanto regras - é que regras e princípios passam a ter o mesmo caráter prima facie. ${ }^{15}$
\end{abstract}

Donde, então, conclui que "princípios são razões prima facie e regras são, se não houver o estabelecimento de alguma exceção, razões definitivas."16

Alexy atenta para o fato de que a explanação supra nunca procede em se tratando de princípios, que são sempre razões prima facie, jamais podendo ser tidos como razões definitivas.

Para ele,

O caminho que vai do princípio, isto é, do direito prima facie, até o direito definitivo passa pela definição de uma relação de preferência. Mas a definição de uma relação de preferência é,

\footnotetext{
${ }^{15}$ Ibidem, p.105.

${ }^{16}$ Ibidem, p. 106.
} 
segundo a lei de colisão, a definição de uma regra. Nesse sentido, é possível afirmar que sempre que um princípio for, em última análise, uma razão definitiva para um juízo concreto de dever ser, então, esse princípio é o fundamento de uma regra, que representa uma razão definitiva para esse juízo concreto. ${ }^{17}$

Para o professor alemão, princípios podem se referir não só a direitos individuais, mas também a interesses coletivos, o que significa que

O fato de um princípio se referir a esses tipos de interesses coletivos significa que ele exige a criação ou a manutenção de situações que satisfaçam, na maior medida possível, diante das possibilidades jurídicas e fáticas, a critérios que vão além da validade ou da satisfação de direitos individuais. ${ }^{18}$

Enquanto as regras possuem grau relativamente baixo de generalidade, os princípios configuram normas dotadas de elevado grau dessa mesma generalidade.

Embora seja a distinção supradeclinada a principal delas ("uma das colunasmestras do edifício da teoria dos direitos fundamentais"19), não é a única; aquela tida por Alexy como a mais correta distinção entre regras e princípios encontra-se, sim, na qualidade, única tese, segundo ele, apta a uma distinção estrita entre as normas.

Desse modo, se é certo que os princípios são efetivamente normas jurídicas, urge especificar que são normas de otimização, ou seja, podem ser cumpridas em distintos graus, dependendo a medida imposta à sua execução não apenas de possibilidades fáticas, senão também de possibilidades jurídicas.

\subsection{A ponderação de princípios $e$ o princípio da}

\section{proporcionalidade}

Segundo Robert Alexy, "se dois princípios colidem - o que ocorre, por exemplo, quando algo é proibido de acordo com um princípio e, de acordo com outro, permitido - , um dos princípios terá que ceder."20

\footnotetext{
${ }^{17}$ Ibidem, p. 108 .

${ }^{18}$ Ibidem, p. 115.

${ }^{19}$ Ibidem, p.85.

${ }^{20}$ Ibidem,p.95.
} 
É preciso estar alerta para o fato de que, sob outras condições presentes em um caso concreto distinto, é possível que a questão da precedência seja resolvida de forma absolutamente contrária.

Desse modo, só há que se falar que um dos princípios tem preferência sobre o outro naquele específico caso, sob aquelas condições determinadas, não significando que o princípios cedente deve ser declarado inválido nem que nele deverá ser incluída uma cláusula de exceção.

Isso porque, de acordo com o caso concreto, os princípios podem apresentar pesos distintos entre si, tendo precedência aquele que apresentar, em determinado caso submetido à solução, o maior. Assim conclui Alexy: "conflitos entre regras ocorrem na dimensão da validade, enquanto a colisão entre os princípios - visto que só princípios podem colidir - ocorrem, para além dessa dimensão, na dimensão do peso."21

A solução da colisão entre princípios está, portanto, no estabelecimento de uma "precedência condicionada",22 entre eles, com base nas circunstâncias de determinado caso concreto.

O fato de um princípio não ter prevalência sobre o outro significa, tão somente, que um deles não teve, naquele determinado caso, peso suficiente para dar-se por decisivo, não havendo que se falar em ausência de validade desse princípio ou ainda, que ele deixou de pertencer ao ordenamento jurídico. ${ }^{23}$

Sintetiza Alexy, que diante de uma colisão de princípios, se isoladamente considerados, ambos os princípios conduzem a
uma contradição. Isso significa, por sua vez, que um princípio
restringe as possibilidades jurídicas de realização de outro. Essa
situação não é resolvida com a declaração de invalidade de um dos
princípios e com sua consequente eliminação do ordenamento
jurídico. Ela tampouco é resolvida por meio da introdução de uma
exceção a um dos princípios, que seria considerado, em todos os
casos futuros, como um regra que ou é realizada, ou não é. A
solução para essa colisão consiste no estabelecimento de uma
relação de precedência condicionada entre os princípios, com base
nas circunstâncias do caso concreto. Levando-se em consideração
o caso concreto, o estabelecimento das relações de precedências
condicionadas consiste na fixação de condições sob as quais um
princípio tem precedência em face do outro. Sob outras condições,

${ }^{21}$ Ibidem, p.94.

${ }^{22}$ Ibidem, p.96.

${ }^{23}$ SILVA, Virgílio Afonso da. Princípios e regras: mitos e equívocos acerca de uma distinção. Revista

Latino-americana de Estudos Constitucionais, v.1., 2003. 
é possível que a questão da precedência seja resolvida de forma contrária $^{24}$.

Através da ponderação procede o julgador à menor restrição possível de um principio naquele caso concreto, prevalecendo, sim, o que com ele colidiu. Fazendo uso de uma metáfora, Luís Roberto Barroso explica: “[...] na solução final, tal qual em um quadro bem pintado, as diferentes cores podem ser percebidas, ainda que uma ou algumas delas venham a se destacar sobre as demais., 25

Necessário, neste ponto do presente estudo, perquirir-se acerca de um dos princípios mais utilizados no embasamento dos juízos de ponderação aqui declinados.

Trata-se do princípio da proporcionalidade ${ }^{26}$.

Segundo Alexy, há uma estreita conexão entre a teoria dos princípios e a máxima da proporcionalidade:

\begin{abstract}
A natureza dos princípios implica a máxima da proporcionalidade, e essa implica aquela. Afirmar que a natureza dos princípios implica a máxima da proporcionalidade significa que a proporcionalidade, com suas três máximas parciais da adequação, da necessidade (mandamento do meio menos gravoso) e da proporcionalidade em sentido estrito (mandamento do sopesamento propriamente dito), decorre logicamente da natureza dos princípios, ou seja, que a proporcionalidade é deduzível dessa natureza. [....] decorre, no fundo, já da própria essência dos direitos fundamentais. ${ }^{27}$
\end{abstract}

Tal princípio, assim, é composto de três subprincípios, elementos ou conteúdos parciais, quais sejam, a pertinência ou aptidão, a necessidade e, por fim, a proporcionalidade stricto sensu.

\footnotetext{
${ }^{24}$ ALEXY, Robert. Teoria dos direitos fundamentais. Tradução de Virgílio Afonso da Silva. São Paulo: Malheiros, 2008, p.96.

25 BARROSO, Luís Roberto.O começo da história: a nova interpretação constitucional e o papel dos princípios no direito brasileiro. In: Direitos humanos e globalização. Rio de Janeiro: Lumen juris, 2004, p.298-341.

${ }^{26}$ Segundo Virgilio Afonso da Silva, mais correto seria falar-se em "regra" da proporcionalidade e não "princípio", nos moldes em que esse último é tratado até este ponto do presente trabalho. Isso porque "impõe um dever definitivo: se for o caso de aplicá-la, essa aplicação não está sujeito a condicionantes fáticas e jurídicas do caso concreto. Sua aplicação é, portanto, feita no todo." In Direitos Fundamentais. Conteúdo essencial, restrições e eficácia. 2.ed. São Paulo: Malheiros, 2011, p.168.

${ }^{27}$ ALEXY, Robert. Teoria dos direitos fundamentais. Tradução de Virgílio Afonso da Silva. São Paulo: Malheiros, 2008, p.117.
} 
Adequação e necessidade traduzem a exigência contida no próprio conceito de princípio no sentido de uma máxima realização dentro das possibilidades fáticas. Decorrem, assim, da natureza dos princípios como mandamentos de otimização em face das possibilidades fáticas. ${ }^{28}$

A adequação possui a natureza de um critério negativo, na medida em que hão de ser eliminados os meios não adequados. Traduz, em poucas palavras, a vedação ao arbítrio.

Alexy exemplifica sua assertiva com o caso de um cabeleireiro que coloca em seu estabelecimento, sem permissão, uma máquina de cigarros, sofrendo a aplicação de uma multa por descumprimento da lei sobre o comércio no varejo.

Isso teria ocorrido pela falta do que chamou de necessária expertise, que poderia ter sido demonstrada pela frequência a um curso profissionalizante como comerciante ou por meio da comprovação da prática diuturna naquela atividade ou, ainda, de um exame especial, no qual seriam testados seus conhecimentos técnicos nessa seara, exigência essa tida por inconstitucional pelo Tribunal alemão, sob os seguintes argumentos:

[...] a exigência de uma prova de expertise para qualquer comércio de qualquer mercadoria - ou seja, também para a exploração de máquinas automáticas para vender cigarros - viola a liberdade profissional, [...] não é adequada para proteger o consumidor contra prejuízos à sua saúde ou contra os prejuízos econômicos. Por essa razão, essa exigência seria proibida pela máxima da adequação e violaria o direito fundamental à liberdade profissional. $^{29}$

Para Alexy, portanto, essa argumentação traduz exatamente sua ideia de otimização, conforme elucida com suas peculiares formulações:

Em jogo estavam dois princípios: o da liberdade profissional (P1) e o da proteção ao consumidor (P2). Por inexistência de adequação, a medida adotada $(\mathrm{M})$ - a exigência de demonstração de competência comercial - não é capaz de fomentar P2, mas embaraça a realização de P1. Nessa situação, não há custos nem para $\mathrm{P} 1$ nem para $\mathrm{P} 2$, caso $\mathrm{M}$ não seja adotada, mas há custos para P1, se M for adotada. P1 e P2, se considerados em conjunto, são realizados em maior grau - relativamente às possibilidades fáticas

\footnotetext{
${ }^{28}$ Ibidem, p.118

${ }^{29}$ Ibidem, p.589.
} 
- se se abrir mão de M. Por conseguinte, P1 e P2, considerados conjuntamente, proíbem a adoção de $\mathrm{M}$. Isso nada mais é do que a expressão da ideia de eficiência de Pareto: uma posição pode ser melhorada sem que uma outra seja piorada. ${ }^{30}$

Já a perquirição acerca da necessidade, também entendida como a proporcionalidade propriamente dita - segundo elemento do princípio sob comento -, a medida adotada há de se ater aos estritos limites exigidos para o alcance do objetivo perseguido, ou seja, exige que o objetivo não possa ser igualmente realizado por meio de outra medida, menos gravosa ao indivíduo, o que decorre do caráter principiológico das normas de direitos fundamentais.

Neste caso, adverte Alexy, não ocorre uma simples eliminação de meios, mas ao legislador também não é prescrita categoricamente a adoção do meio que intervém em menor intensidade. E segue: “o que se diz apenas é que, se o legislador quiser perseguir o objetivo escolhido, ele pode adotar o meio mais suave", traduzindo-se em verdadeira "vedação de sacrifícios desnecessários a direitos fundamentais." 31

Traz como exemplo da manifestação do princípio da proporcionalidade na sua faceta necessidade o seguinte caso:

\begin{abstract}
Uma portaria do Ministério da Juventude, Família e Saúde continha a proibição da comercialização de doces que, embora contivessem chocolate em pó, eram feitos sobretudo de flocos de arroz e não eram, portanto, produtos genuinamente de chocolate. $\mathrm{O}$ objetivo dessa portaria era proteger o consumidor contra compras equivocadas. O Tribunal Constitucional Federal observou que uma tal proibição de comercialização de mercadorias seria inteiramente adequada para proteger o consumidor. Se há proibição de que algo seja comercializado, o risco de que ele seja comprado por engano é pequeno. No entanto, a proibição de comercialização não seria necessária. [...]. Um dever de identificação no rótulo poderia combater o perigo de confusões e equívoco de maneira igualmente eficaz, mas de forma menos invasiva. ${ }^{32}$
\end{abstract}

Seria, em última análise, a popularmente conhecida "teoria do mal menor", nos dizeres também do publicista francês Xavier Philippe, citado por Bonavides: "pela

\footnotetext{
${ }^{30}$ Ibidem, p.589.

${ }^{31}$ Ibidem, p.591.

${ }^{32}$ Ibidem, p.590.
} 
necessidade não se questiona a escolha operada, mas o meio empregado e que este deve ser dosado para chegar ao fim pretendido." 33

Como último elemento, ter-se-ia a proporcionalidade tomada stricto sensu, devendo-se, através da sua utilização, perquirir-se acerca do meio ou dos meios que, num determinado caso concreto, estaria(m) levando mais em conta o conjunto dos interesses em análise. Segundo o jurista germânico, tal definição em nada difere da lei do sopesamento, que apresenta a seguinte redação: "quanto maior for o grau de não-satisfação ou de afetação de um princípio, tanto maior terá que ser a importância da satisfação do outro.”34

\begin{abstract}
Princípios são mandamentos de otimização em face das possibilidades jurídicas $e$ fáticas. A máxima da proporcionalidade em sentido estrito, ou seja, a exigência de sopesamento, decorre da relativização em face das possibilidades jurídicas. Quando uma norma de direito fundamental com caráter de princípio colide com um princípio antagônico, a possibilidade jurídica para a realização dessa norma depende do princípio antagônico. Para se chegar a uma decisão, é necessário um sopesamento nos termos da lei de colisão. Visto que a aplicação de princípios válidos - caso sejam aplicáveis - é obrigatória, e visto que para essa aplicação, nos casos de colisão, é necessário um sopesamento, o caráter principiológico das normas de direitos fundamentais implica a necessidade de um sopesamento quando elas colidem com princípios antagônicos. Isso significa, por sua vez, que a máxima da proporcionalidade em sentido estrito é deduzível do caráter principiológico das normas de direitos fundamentais. ${ }^{35}$
\end{abstract}

E conclui:

A lei do sopesamento mostra que ele pode ser dividido em três passos. No primeiro é avaliado o grau de não satisfação ou afetação de um dos princípios. Depois, em um segundo passo, avalia-se a importância da satisfação do princípio colidente. Por fim, em um terceiro passo, deve ser avaliado se a importância da satisfação do princípio colidente justifica a afetação ou nãosatisfação do outro princípio ${ }^{36}$.

O autor, por sua vez, não deixa de reconhecer a existência de uma série de óbices ao seu pensamento e é através delas que melhor explica os meandros da

33 PHILIPPE, Xavier apud BONAVIDES, Paulo. Curso de direito constitucional. 24.ed. São Paulo: Malheiros, 2009, p.397.

${ }^{34}$ ALEXY, Robert. Teoria dos direitos fundamentais. Tradução de Virgílio Afonso da Silva. São Paulo: Malheiros, 2008, p.593.

${ }^{35}$ Ibidem, p. 118.

${ }^{36}$ Ibidem, p.594 
ponderação, a respeito da qual declara ser objeção frequente a ausência de um controle racional.

E prossegue: "valores e princípios não disciplinam sua própria aplicação, e o sopesamento, portanto, ficaria sujeito ao arbítrio daquele que sopesa, [...] e abriria espaço para o subjetivismo e o decisionismo dos juízes."37

Discorda, porém, argumentando que o sopesamento não se resume pura e simplesmente à formulação de um enunciado de preferências para, assim, chegar-se à regra decorrente deste enunciado relativo ao caso, uma vez que, se assim fosse, de fato não se poderia classificá-lo como um procedimento racional, dado que tal preferência condicionada seria fruto de mera intuição.

Por isso, aduz haver um modelo fundamentado e não simplesmente decisionista de sopesamento, modelo este que, embora chegue ao mesmo resultado - um enunciado de preferência condicionado - é, sim, dotado de racionalidade.

\title{
Segundo Willis Santiago Guerra,
}

\begin{abstract}
a aplicação das normas jurídicas, especialmente tratando-se dos princípios, requer procedimentos institucionalizados e, também, procedimentos (meramente) cognitivos, realizados no âmbito dos primeiros, onde se dá o confronto de diversas argumentações, a respeito das inúmeras possibilidades de interpretação dessas normas, para aplicá-las, criando, assim, as condições para discussões e decisões cuja racionalidade se ode aferir, na medida em que são objetivamente fundamentadas. ${ }^{38}$
\end{abstract}

Retirada das formulações do Tribunal Constitucional Federal alemão, a defesa em prol de argumentos relacionados especificamente ao sopesamento e que lhe dariam racionalidade é sintetizada como “a lei do sopesamento”, lei esta já declinada.

Segundo ele,

\begin{abstract}
$\mathrm{Na}$ própria definição do conceito de princípio, com a cláusula "dentro das possibilidades jurídicas", aquilo que é exigido por um princípio foi inserido em uma relação com aquilo que é exigido pelo princípio colidente. A lei de colisão expressa em que essa relação consiste. Ela faz com que fique claro que o peso dos
\end{abstract}

\footnotetext{
${ }^{37}$ Ibidem, p.164.

${ }^{38}$ GUERRA FILHO, Willis Santiago. Princípio da proporcionalidade e teoria do direito. In GRAU, Eros Roberto; GUERRA FILHO, Willis Santiago (org.). Direito Constitucional. Estudos em homenagem a Paulo Bonavides. São Paulo: Malheiros, pp.268-283.
} 
princípios não é determinado em si mesmo ou de forma absoluta e que só é possível falar em pesos relativos. ${ }^{39}$

O próprio Alexy reconhece que esses conceitos referentes à satisfação e à afetação levam a resultados subjetivos, muito embora insista na existência de uma racionalidade no método que expõe.

Assim, defende que essa regra é de todo pertinente pelo fato de que diz o que deve ser fundamentado para se justificar o enunciado de preferência, resultado do sopesamento, ou seja, devem sê-lo os "enunciados sobre graus de afetação e de importância." 40

Para cumprir tal desiderato, prossegue dizendo ser possível fazer uso de qualquer motivação típica de uma argumentação jurídica, citando dentre estes argumentos a referência a fatos, a regularidades empíricas e juízos normativos, e advoga: "um tal conjunto de razões - que inclui valorações - é algo característico da fundamentação jurídica", concluindo:

[...] do próprio conceito de princípio decorre a constatação de que os sopesamentos não são uma questão de tudo-ou-nada, mas uma tarefa de otimização. Nesse sentido, o modelo de sopesamento aqui defendido é equivalente ao assim chamado princípio da concordância prática. ${ }^{41}$

Ainda sobre as objeções ao seu estudo, aponta Alexy a inexistência de um parâmetro para a decisão do sopesamento, razão pela qual muitos a ele se referem como uma "fórmula vazia"42.

A isso acresce a tese de que os sopesamentos conduziriam a decisões particulares e, por fim, a crítica de que tal sopesamento não passa de uma palavra pela outra.

Busca, então, rebater todas elas.

\footnotetext{
${ }^{39}$ ALEXY, Robert. Teoria dos direitos fundamentais. Tradução de Virgílio Afonso da Silva. São Paulo: Malheiros, 2008, p.168.

${ }^{40}$ Ibidem, p. 171.

${ }^{41}$ Ibidem, p. 173.

${ }^{42}$ Ibidem, p. 175.
} 
Quanto à primeira objeção, aduz que o modelo do sopesamento oferece, sim, um critério, via associação da teoria de colisão com a teoria da argumentação jurídica racional, fornecendo a lei de colisão o norte do que deve ser fundamentado de forma racional.

Já quanto à possibilidade de decisões particulares, atesta que as decisões provindas de sopesamentos são decisões judiciais e, como tais, provêm exatamente de casos particulares. Contudo, resta sempre possível daí se formular uma regra, partindo-se do particular para uma universalização. Neste ponto, também observa Luís Roberto Barroso:

\begin{abstract}
No estágio atual, a ponderação ainda não atingiu o padrão desejável de objetividade, dando lugar a ampla discricionariedade judicial. Tal discricionariedade, no entanto, como regra, deverá ficar limitada às hipóteses em que o sistema jurídico não tenha sido capaz de oferecer a solução em tese, elegendo um valor ou interesse que deva prevalecer.[...] O controle de legitimidade das decisões obtidas mediante ponderação tem sido feito através do exame da argumentação desenvolvida. Seu objetivo, de forma bastante simples, é verificar a correção dos argumentos apresentados em suporte de uma determinada conclusão ou ao menos a racionalidade do raciocínio desenvolvido em cada caso, especialmente quando se trate do emprego da ponderação ${ }^{43}$.
\end{abstract}

Finalmente, para Alexy, "um princípio é contraposto a outro princípio, e a consequência é aquilo que é previsto na lei de colisão e sopesamento" ${ }^{\text {,4 }}$, não constituindo este último, assim, mero jogo de palavras.

\title{
1.3. Direitos sociais e ponderação
}

A partir deste item, buscamos demonstrar o que são direitos sociais para Alexy e, ainda, se esses mesmos direitos são, também, ponderáveis.

Alexy parte da interpretação liberal clássica dos direitos fundamentais quanto à atuação estatal, sendo que há aqueles direitos, tidos como de primeira dimensão,

\footnotetext{
${ }^{43}$ BARROSO, Luís Roberto.O começo da história: a nova interpretação constitucional e o papel dos princípios no direito brasileiro. In: Direitos humanos e globalização: fundamentos desde a teoria crítica. Rio de Janeiro: Lumen juris, 2004, p.298-341.

${ }^{44}$ ALEXY, Robert. Teoria dos direitos fundamentais. Tradução de Virgílio Afonso da Silva. São Paulo: Malheiros, 2008, p.174.
} 
que se referem à não intervenção estatal nas liberdades públicas, ou seja, deve o Poder Público abster-se frente a tais direitos. Consubstanciam, em última análise, direitos de defesa dos cidadãos contra o Estado.

Posição distinta exige-se deste ente quando se trata dos direitos fundamentais de proteção, também chamados de direitos fundamentais de segunda dimensão, demandando a atuação positiva do ente público na sua efetivação.

Assim, melhor explicita:

todo direito a uma ação positiva, ou seja, a uma ação do Estado, é um direito a uma prestação. Nesse sentido, o conceito de direito a prestações é exatamente o oposto do conceito de direito de defesa, no qual se incluem todos os direitos a uma ação negativa, ou seja, a uma abstenção estatal. ${ }^{45}$

Para Robert Alexy, "saber em que medida se deve atribuir aos dispositivos de direitos fundamentais normas que garantam direitos a prestação em sentido amplo é uma das questões mais polêmicas da dogmática dos direitos fundamentais." ${ }^{46}$

Assim, de início, dá como exemplo de direitos fundamentais sociais os direitos à assistência social, ao trabalho, à moradia e à educação, mas já esclarece que, em que pese tais direitos constituam uma importante parte dos direitos a prestação, o âmbito desses direitos é ainda mais amplo.

\begin{abstract}
A escala de ações estatais positivas que podem ser objeto de um direito a prestação estende-se desde a proteção do cidadão contra outros cidadãos por meio de normas de direito penal, passa pelo estabelecimento de normas organizacionais e procedimentais e alcança até prestações em dinheiro e outros bens. ${ }^{47}$
\end{abstract}

Cumpre ressaltar que a questão que envolve os direitos sociais, na Alemanha, possui contornos absolutamente distintos quando em comparação com os direitos sociais na Constituição Federal brasileira. Isso porque

\footnotetext{
A Constituição alemã, com pouquíssimas exceções, não contém direitos fundamentais sociais formulados de maneira expressa; mesmo assim discute-se, com grande empenho e veemência se, em caso afirmativo, quais os direitos fundamentais sociais são por ela garantidos, constituindo, assim, verdadeira polêmica sobre a obrigação ou vedação de se atribuir aos dispositivos de direitos
}

\footnotetext{
${ }^{45}$ Ibidem, p.442.

46 Ibidem, p.433.

${ }^{47}$ Ibidem, p.442.
} 
fundamentais normas que garantam direitos fundamentais
sociais." 48

Houve, nos dizeres do próprio autor, uma "renúncia consciente do legislador à formulação de normas garantidoras de direitos subjetivos a prestações", admitindo, todavia, a possibilidade de se extrair da Constituição o que chama de pontos de apoio, formulados de forma objetiva, para uma interpretação no sentido da existência de direitos à prestação.

Nesse sentido, menciona:

[...] "a obrigação de todos os poderes estatais" de "proteger" a dignidade humana (art. $1^{\circ}$, parágrafo $1^{\circ}, 2$, da Constituição alemã) e a cláusula do Estado Social (art.20, par. $1^{\circ}$ e art.28, par. $\left.1^{\circ}, 1\right)$. Além disso, são também dignos de menção a garantia de proteção ao matrimônio e à família $\left(\operatorname{art} .6^{\circ}\right.$, par. $\left.1^{\circ}\right)$ e o mandamento constitucional no sentido de equiparação de filhos ilegítimos $\left(\operatorname{art} .6^{\circ} \text {, parágrafo } 5^{\circ}\right)^{49}$

Sempre reconhecendo, de grande relevância para o nosso estudo, que

Contudo, esses dispositivos - tanto quanto a possibilidade de que o enunciado geral de igualdade fundamente direitos derivados a prestações, além de poder ser interpretada como um princípio de igualdade fática, o qual, em casos especiais também pode fundamentar direitos originários a prestações - não podem ocultar o fato de que a Constituição, a partir de seu texto e da história de sua elaboração, tem caráter de uma Constituição de um Estado de Direito burguês, precipuamente orientada por direitos de defesa. [...] apenas no texto da Constituição alemã, é possível encontrar como formulação explícita de um direito fundamental social no sentido de um direito subjetivo a uma prestação apenas o direito da mãe à proteção e à assistência da comunidade (artigo $6^{\circ}$, parágrafo $4^{\circ}$ da Constituição alemã)." 50

Assim, divide os direitos a prestação em sentido amplo em três grupos: 1) direitos a proteção; 2) direitos a organização e procedimento e 3) direitos a prestações em sentido estrito, alertando que "os direitos dessa natureza podem ser considerados direitos a prestações somente se se tratar de direitos subjetivos e de nível constitucional." ${ }^{51}$

\footnotetext{
${ }^{48}$ Ibidem, p.500.

${ }^{49}$ Ibidem, p.435

${ }^{50}$ Ibidem, p.435

51 ibidem, p.445.
} 
Feitos esses esclarecimentos, a partir daqui nos ateremos aos direitos a prestações em sentido estrito, pois é a eles, especificamente, que Robert Alexy denomina de direitos fundamentais sociais.

Assim, conceitua tais direitos como sendo

\begin{abstract}
direitos do indivíduo em face do Estado, a algo que o indivíduo, se dispusesse de meios financeiros suficientes e se houvesse uma oferta suficiente no mercado, poderia também obter de particulares. Quando se fala em direitos fundamentais sociais como, por exemplo, direitos à assistência à saúde, ao trabalho, à moradia e à educação, quer-se primariamente fazer menção a direitos a prestação em sentido estrito. ${ }^{52}$
\end{abstract}

De acordo com o autor alemão, em se tratando de direitos fundamentais sociais, existem várias classificações possíveis, seja do ponto de vista teórico-estrutural, podendo ser normas que garantam direitos subjetivos ou normas que apenas obrigam o Estado de forma objetiva; normas vinculantes ou não-viculantes (meros enunciados programáticos) e, ainda, normas que fundamentam direitos e deveres definitivos ou prima facie, isto é, regras ou princípios, assim dispondo:

\begin{abstract}
A proteção mais intensa é garantida pelas normas vinculantes que outorgam direitos subjetivos definitivos a prestações (1); a proteção mais fraca, pelas normas não-vinculantes que fundamentam apenas um dever estatal objetivo prima facie à realização de prestações (8): o direito a ser admitido no curso universitário de sua escolha, que, embora conferido, em princípio, ao cidadão que tenha concluído o ensino médio, está sob a "reserva do possível". [...] esse direito deve ser visto como um direito subjetivo prima facie vinculante. Por fim, um direito subjetivo definitivo vinculante é o direito a um "mínimo existencial $^{53}$.
\end{abstract}

Além das diferenças supra, tidas como estruturais, Alexy fala ainda em diferenças substanciais, variando de acordo com o conteúdo minimalista ou maximalista que se atribua aos direitos sociais, de modo que o primeiro "tem como objetivo garantir ao indivíduo o domínio de um espaço vital e de um status social mínimos, ou seja, aquilo que é chamado de "direitos mínimos" e " pequenos direitos sociais". Já o conteúdo maximalista pode ser percebido quando se fala de uma "realização completa" dos direitos

\footnotetext{
52 Ibidem, p.499.

${ }^{53}$ Ibidem, p.502.
} 
fundamentais." Assim, conclui:"o problema dos direitos fundamentais sociais não pode ser resumido a uma questão de tudo-ou-nada." 54

Desse modo, para aqueles que se posicionam favoravelmente aos direitos fundamentais sociais, sua justificativa estaria, basicamente, jungida ao conceito de liberdade real, ou seja, de nenhuma valia tem a existência de direitos de liberdade se não há, de fato, a liberdade de escolher entre as alternativas permitidas, constituindo os direitos sociais, assim, pressupostos fáticos pata o exercício da liberdade real.

Questiona Robert Alexy se aos direitos sociais, caso existentes, caberia o papel de garantir essa liberdade fática ou se esta seria atribuição do Estado via processo político, e assim constrói o seguinte raciocínio: "para justificar a atribuição de direitos fundamentais sociais com o auxílio de um argumento baseado na liberdade, é necessário também fundamentar por que a liberdade garantida pelos direitos fundamentais inclui a liberdade fática" ${ }^{55}$ e, para isso, apresenta dois argumentos que podem ser então utilizados:

\begin{abstract}
O primeiro baseia-se na importância da liberdade fática para $o$ indivíduo. [...] é de vital importância [para o indivíduo] não viver abaixo do mínimo existencial, não estar condenado a um desemprego de longo prazo e não estar excluído da vida cultural de seu tempo.[...] É exatamente aquele desprovido de meios que pode valorizar especialmente aqueles direitos fundamentais que, por exemplo, o protegem contra trabalho forçado e outras situações semelhantes e aqueles que lhe dão a possibilidade de melhorar a sua situação por meio do processo político. [...] para ele, a eliminação de sua situação de necessidade é mais importante que as liberdades jurídicas, que a ele de nada servem, em razão dessa situação de necessidade, e que, por isso, são para ele uma "fórmula vazia". Se a esse cenário se adiciona o fato de que a razão de ser dos direitos fundamentais é exatamente a de que aquilo que é especialmente importante para o indivíduo, e que pode ser juridicamente protegido, deve ser juridicamente garantido, então, o primeiro argumento para a proteção no âmbito dos direitos fundamentais está completo. ${ }^{56}$
\end{abstract}

Já o segundo argumento, segue o autor, está diretamente ligado ao supra

[...] dentre outros, princípios que exijam que o indivíduo possa desenvolver livremente sua dignidade na comunidade social, o que pressupõe uma certa medida de liberdade fática. A conclusão inevitável é a de que os direitos fundamentais, se seu escopo for o

\footnotetext{
${ }^{54}$ Ibidem, p.502.

${ }^{55}$ Ibidem, p.505.

${ }^{56}$ Ibidem, p.506.
} 
livre desenvolvimento da personalidade humana, também estão orientados para a liberdade fática, ou seja, também devem garantir os pressupostos do exercício das liberdades jurídicas, sendo assim, não apenas a regulação das possibilidades jurídicas, mas também do poder de agir fático. ${ }^{57}$

Como ressaltado pelo jurista alemão em diversas de suas passagens, inúmeras são as objeções contra a própria existência dos direitos sociais como direitos efetivamente fundamentais, consubstanciando tais objeções em dois argumentos, um formal e um substancial:

O argumento formal aponta para um dilema: se os direitos fundamentais sociais forem vinculantes, eles deslocam a política social da competência parlamentar para a competência do tribunal constitucional; se eles não forem vinculantes, eles implicam uma violação da cláusula de vinculação do art.1 $1^{\circ}$, par. $3^{\circ}$, da Constituição alemã. $\mathrm{O}$ ponto de partida desse argumento é a tese de que os direitos fundamentais sociais ou não são justiciáveis ou o são apenas em pequena medida. ${ }^{58}$

E assim prossegue dizendo que o argumento formal parte do fato de que o objeto dos direitos sociais são extremamente indeterminados, não sendo possível se precisar qual o conteúdo da maioria deles.

Qual é, por exemplo, o conteúdo de um direito fundamental ao trabalho? A escala de possíveis interpretações vai desde um direito utópico de todos a qualquer trabalho que se deseje, em qualquer lugar e em qualquer momento, até um direito compensatório a um auxílio-desemprego. Mas qual deve ser o valor desse auxílio ${ }^{59}$

Já de acordo com o argumento que denomina "substancial" contra os direitos sociais, sustenta o autor que eles são incompatíveis - ou ao menos colidem - com normas constitucionais materiais - direitos de liberdade, sendo com elas incompatíveis. Assim exemplifica:

A colisão entre direitos fundamentais sociais e direitos de
liberdade é especialmente clara no caso do direito ao trabalho. Em
uma economia de mercado, o Estado tem controle apenas limitado
sobre o objeto desse direito. Se ele quisesse satisfazer diretamente
um direito de cada desempregado a um posto de trabalho, ele teria
que ou empregar todos os desempregados nos serviços públicos
existentes, ou restringir ou eliminar o poder econômico privado de

\footnotetext{
${ }^{57}$ Ibidem, p.506.

${ }^{58}$ Ibidem, p.507.

${ }^{59}$ Ibidem, p.507.
} 
dispor sobre postos de trabalho. A primeira solução, pelo menos como solução geral, está fora de questão, pois conduziria, nas condições existentes, simplesmente a um desemprego disfarçado pelo serviço público. A segunda conduziria ou a uma extensa restrição da competência decisória da economia privada, ou a uma eliminação dessa forma de economia. Mas isso significaria, entre outras coisas, intervenções nos direitos fundamentais daqueles que dispõem da propriedade produtiva. ${ }^{60}$

Assim, ao ressaltar, ainda, o caráter extremamente custoso dos direitos sociais, adverte para o fato de que

Para a realização dos direitos fundamentais sociais o Estado pode apenas distribuir aquilo que recebe de outros, por exemplo, na forma de impostos e taxas. Mas isso significa que os frequentemente suscitados limites da capacidade de realização do Estado não decorrem apenas dos bens distribuíveis existentes, mas sobretudo daquilo que o Estado, para fins distributivos, pode tomar dos proprietários desses bens sem violar seus direitos fundamentais. ${ }^{61}$

Pontua, outrossim, que direitos fundamentais sociais colidiriam, ainda, com direitos de liberdade do próprio titular do direito social, exemplificando com o direito ao trabalho que implica num dever de trabalhar, colisão esta que, embora frequente, nem sempre ocorre:

\footnotetext{
o interesse em trabalhar, sobretudo o interesse em um salário, pode ser, para um número suficiente de cidadãos, um incentivo suficiente para exercer o direito ao trabalho. No entanto, algo distinto pode ser verdadeiro se o direito ao mínimo existencial já coloca o indivíduo em uma situação na qual o exercício do direito do trabalho deixa de ser atrativo para ele. ${ }^{62}$
}

Faz alusão, por fim, à colisão dos direitos sociais com os interesses coletivos ou mesmo com outros direitos fundamentais sociais. No primeiro caso, exemplifica com a defesa nacional - "a realização de ambos [direitos sociais e interesse coletivo] exige uma parte considerável do orçamento, ou seja, decorrem do já mencionado efeito financeiro dos direitos fundamentais sociais" ${ }^{63}$

\footnotetext{
${ }^{60}$ Ibidem, p.510

${ }^{61}$ Ibidem, p.510.

${ }^{62}$ Ibidem, p.511.

${ }^{63}$ Ibidem.
} 
Propõe então Alexy como solução um modelo que leve em conta tanto os argumentos a favor como aqueles contrários aos direitos sociais, modelo consubstanciado no que chama de "ideia guia", ou seja, "os direitos fundamentais da Constituição alemã são posições que, do ponto de vista do direito constitucional, são tão importantes que a decisão sobre garantí-las não pode ser simplesmente deixada para a maioria parlamentar simples."

\title{
E segue:
}

De acordo com essa fórmula, a questão acerca de quais direitos fundamentais sociais o indivíduo definitivamente tem é uma questão de sopesamento entre princípios. De um lado está, sobretudo, o princípio da liberdade fática. Do outro lado estão os princípios formais da competência decisões do legislador democraticamente legitimado e o princípio da separação de poderes, além de princípios materiais, que dizem respeito sobretudo à liberdade jurídica de terceiros, mas também a outros direitos fundamentais sociais e a interesses coletivos.

Dessa forma, muito embora reconheça que essa fórmula não fornece uma resposta precisa acerca de quais direitos fundamentais sociais o indivíduo possui, sendo esta tarefa da dogmática de cada um deles, entende ser possível, sim, uma resposta geral:

\begin{abstract}
Uma posição no âmbito dos direitos a prestações tem que ser vista como definitivamente garantida se (1) o princípio da liberdade fática a exigir de forma premente e se (2) o princípio da separação de poderes e o princípio democrático (que inclui a competência orçamentária do parlamento) bem como (3) os princípios materiais colidentes (especialmente aqueles que dizem respeito à liberdade jurídica de outrem) forem afetados em uma medida relativamente pequena pela garantia constitucional da posição prestacional e pelas decisões do tribunal constitucional que a levarem em consideração. Essas condições são necessariamente satisfeitas no caso dos direitos fundamentais sociais mínimos, ou seja, por exemplo, pelos direitos a um mínimo existencial, a uma moradia simples, à educação fundamental e média, à educação profissionalizante e a um patamar mínimo de assistência médica. ${ }^{64}$
\end{abstract}

Ainda que defenda apenas a realização do mínimo quando se trata da efetivação dos direitos fundamentais sociais, Alexy alerta, mais uma vez, para o custo gerado por eles: 
impossível a necessária flexibilidade em tempos de crise e poderia transformar uma crise econômica em uma crise constitucional. ${ }^{65}$

E quando nos vemos no limiar da desesperança total na sua teoria face às exigências de uma solidariedade social, ele, assim, pondera, dizendo ser necessário, contudo observar:

[...] nem tudo aquilo que em um determinado momento é considerado como direitos sociais é exigível pelos direitos fundamentais sociais mínimos; em segundo lugar, que, de acordo com o modelo aqui proposto, os necessários sopesamentos podem conduzir, em circunstâncias distintas, a direitos definitivos distintos; e, em terceiro lugar, que é exatamente nos tempos de crise que a proteção constitucional, ainda que mínima, de posições sociais parece ser imprescindível. ${ }^{66}$

\footnotetext{
${ }^{65}$ Ibidem, p.513.

${ }^{66}$ Ibidem, p.513.
} 


\section{CAPÍTULO 2 \\ O PÓS-POSITIVISMO DE ALEXY E A JURISPRUDÊNCIA \\ TRABALHISTA}

"Cai o rei de espadas

Cai o rei de ouro

Cai o rei de paus

Cai, não fica nada."

- Elis Regina

Partindo da compreensão da teoria Pós-positivista de Robert Alexy, favorecida pelo estudo acima realizado, o presente capítulo tem o escopo de demonstrar que, muito embora algumas decisões façam referência ao Pós-positivismo de Alexy, de fato não estão adotando referida doutrina.De início, cabe verificar que muitos julgados atribuem ao referido autor um conceito de princípio que não é por ele em momento algum adotado, vide, por exemplo, o seguinte julgado:

De acordo com o dicionário Houaiss, a palavra princípio traduz o começo, o início, "o primeiro momento da existência (de algo) ou de uma ação ou processo". Também pode ser considerada como causa primeira, raiz, razão, "o que serve de

base a alguma coisa". Significa ainda a "proposição elementar e fundamental que serve de base a uma ordem de conhecimentos" e "proposição lógica fundamental sobre a qual se apoia o raciocínio".

Para Miguel Reale:

“(...) princípios são verdades fundantes de um sistema de conhecimento, como tais admitidas por serem evidentes ou por terem sido comprovadas, mas também por motivos de ordem prática de caráter operacional, isto é, como pressupostos exigidos pelas necessidades da pesquisa e da praxis. 
Pode-se afirmar, pois, que os princípios constituem verdadeiras proposicões lógicas, servindo, inclusive, de embasamento de todo o sistema jurídico.

Os princípios, entretanto, tiveram que conquistar o "status" de norma jurídica, superando a crença de que teriam uma dimensão puramente axiológica, ética, sem eficácia jurídica ou aplicabilidade direta e imediata.

A dogmática moderna avaliza o entendimento de que as normas em geral e as normas constitucionais em particular, enquadram-se em duas grandes categorias diversas: os princípios e as regras. Antigamente a distinção entre eles fundava-se, sobretudo, no critério da generalidade. Todavia, nos últimos tempos, a distinção passou a ser qualitativa ou estrutural, sendo que o princípio veio a se tornar um dos pilares da moderna dogmática constitucional, indispensável para a superação do positivismo legalista, onde as normas se cingiam a regras jurídicas.

A Constituição passa a ser encarada como um sistema aberto de princípios e regras, permeável a valores jurídicos suprapositivos, no qual as ideias de justiça e de realização dos direitos fundamentais desempenham um papel central.

A mudança de paradigma nessa matéria deve especial tributo às concepcões de Ronald Dworkin e aos desenvolvimentos a ela dados por Robert Alexy. A conjugação das ideias desses dois autores dominou a teoria jurídica e passou a constituir o conhecimento convencional na matéria.

Rizzato Nunes explicita claramente a atuação dos princípios e das normas no interior do sistema jurídico:

"Normas jurídicas funcionam como regras, e estas são fundamentadas nos princípios. Estes, portanto, têm um grau incomparavelmente mais alto de generalidade (referente à classe de indivíduos a que a norma se aplica) e abstração (referente à espécie de fato a que a norma se aplica) do que a mais geral e abstrata das regras. Agora, diga-se que os princípios situam-se no ponto mais alto de qualquer sistema jurídico, de forma genérica e abstrata, mas essa abstração não significa inincidência no plano da realidade. É que, como as normas jurídicas incidem no real e como devem respeitar os princípios, acabam por levá-los à concretude".

Os princípios constitucionais, por sua vez, são aqueles que guardam os valores fundamentais da ordem jurídica. É neles que se condensam os bens e valores considerados fundamentos de validade de todo o sistema jurídico. É o ápice do sistema jurídico, tudo que lhes segue tem que estar em perfeita harmonia e em conformidade com seus preceitos, servindo inclusive de critérios para as futuras normas.

Conclui-se, pois, que os princípios são o ápice, a viga-mestra do sistema jurídico, sendo o seu fundamento de validade, embasamento e sistematização. Constituem a raiz de onde deriva a validade intrínseca do conteúdo das normas jurídicas, servindo de fundamento ao direito positivo.

Além disso, servem de critério de interpretação, como guia e orientação na busca do sentido e alcance das normas jurídicas, 
decorrendo tal fato logicamente de sua função fundamentadora do direito. $^{67}$ [grifos nossos]

Percebe-se, pelo julgado em questão, o desconhecimento das ideias do autor citado, uma vez que se refere a princípios como normas que "guardam os valores fundamentais da ordem jurídica", neles se condensando "bens e valores considerados fundamentos de validade de todo o sistema jurídico", constituindo, em última análise, "o ápice, a viga-mestra do sistema jurídico" e, em seguida, diz estar se apoiando nos ensinamentos de Robert Alexy. Mas, como visto, não é essa a base da teoria de do autor alemão, que, de fato, sequer se preocupa em atribuir um conceito ao princípio e muito menos conferir-lhe uma posição de fundamentalidade frente à regras. Princípio, para Alexy, é definido pelo seu modo de aplicação, conforme deixa certo o seu caráter de máxima de otimização.

Com efeito, segundo aponta Virgílio Afonso da Silva, tradutor da principal obra na qual baseamos nosso estudo - Teoria dos Direitos Fundamentais - e que realizou seus estudos na Alemanha sob orientação de Alexy:

O conceito de princípio, na teoria de Alexy, é um conceito que nada diz sobre a fundamentalidade da norma. Assim, um princípio pode ser um "mandamento nuclear do sistema", mas pode também não o ser, já que a norma é um princípio apenas em razão de sua estrutura normativa e não de sua fundamentalidade. ${ }^{68}$

Desse modo, segue o autor,

Muito do que as classificações tradicionais chamam de princípio, deveriam ser, se seguirmos a forma da distinção proposta por Alexy, chamado de regra. Assim, falar em princípio do nulla poena sine lege, em princípio da legalidade, em princípio da anterioridade, entre outros, só faz sentido para as teorias tradicionais. Se se adotam os critérios propostos por Alexy, essas normas são regras, não princípios. [...] Como se percebe, o conceito de princípio, na teoria de Alexy é um conceito axiologicamente neutro. ${ }^{69}$

\footnotetext{
${ }^{67}$ TRT 15 ${ }^{\mathrm{a}}$ Região, RO 0079400-06-2009.5.15.0002, Relatora Maria Cecília Álvares Leite, $6^{\mathrm{a}}$ Turma, Julgado em 20/02/2011, DEJT 25/02/2014.

68 SILVA, Virgilio Afonso da. Princípios e regras: mitos e equívocos acerca de uma distinção. Revista Latino-Americana de Estudos Constitucionais, v.1, 2003, pp.607-630, p.613.

${ }^{69}$ Ibidem.
} 
Ademais, como visto, Alexy realiza seu estudo utilizando exemplos práticos angariados na jurisprudência do Tribunal alemão acerca de determinados direitos fundamentais vigentes. "Se trata se una teoría de los derechos fundamentales de la Ley Fundamental de Bonn que se apoya insistentemente en la jurisprudencia del Tribunal Federal Alemán". 70

Apresenta, assim, basicamente, hipóteses de leis e demais atos normativos estatais que restringem direitos fundamentais e, desse modo, só podem ser tidos como constitucionais se forem fruto de um sopesamento racional, sopesamento este que será analisado pelo magistrado, por meio do controle de constitucionalidade.

Trata-se, então, de uma teoria desenvolvida com vistas à solução de problemas de controle de constitucionalidade de atos estatais, não se voltando à análise de caso concreto, muito embora esta seja sua principal utilização na seara trabalhista.

Demais disso, a teoria de Alexy, na análise da constitucionalidade dessas leis, direciona seu estudo, primordialmente, às hipóteses de restrição ao que chama de direitos de liberdades, procedida pelo ente estatal. Seu objeto de pesquisa, desse modo, não são os direitos sociais, tanto que dedica apenas um pequeno espaço em sua obra para o trato desses direitos, conforme analisado no presente trabalho, em capítulo próprio.

Já nas primeiras páginas de sua Teoria dos Direitos Fundamentais, Alexy consigna que se trata de uma teoria baseada nos direitos fundamentais da Constituição alemã, constituição esta que, como visto, não traz direitos fundamentais sociais em seu conteúdo. Assim dispõe:

\begin{abstract}
A análise a ser aqui desenvolvida diz respeito a uma teoria jurídica geral dos direitos fundamentais da Constituição alemã. [...] Uma teoria dos direitos fundamentais da Constituição alemã é uma teoria acerca de determinados direito fundamentais positivos vigentes. Isso a diferencia tanto de teorias sobre direitos fundamentais que tenham vigido no passado (teorias históricojurídicas), como de teorias sobre direitos fundamentais per se (teorias filosófico-jurídicas), como de teorias sobre direitos fundamentais que não os da Constituição alemã - por exemplo, teoria sobre direitos fundamentais de outros países ${ }^{71}$.
\end{abstract}

\footnotetext{
${ }^{70}$ ALEXY, Robert; BASTIDA, Francisco J.; AMADO, Juán Antonio Garcia; VALDÉS, Liborio L. Hierro, MORESO, José Juan; PARDO, Celestino; PECES BARBA, Gregorio. Derechos sociales y ponderación. 2.ed. Madri: J.Sán José, 2009, p.18.

${ }^{71}$ ALEXY, Robert. Teoria dos direitos fundamentais. Tradução de Virgílio Afonso da Silva. São Paulo: Malheiros, 2008, p.32.
} 
Mesmo que assim não fosse, o conceito de direitos sociais, para o jurista alemão, difere daquele que propugnamos. Segundo ele, direitos sociais se restringem àqueles que demandam uma atuação positiva do Estado, tais como saúde, educação, e são importantes apenas na medida em que viabilizam o exercício dos direitos de liberdade. Não inclui o Direito do Trabalho, portanto. Cumpre ressaltar, outrossim, o que reforça nosso argumento, que a Constituição alemã não possui qualquer artigo tratando de Direito do Trabalho ${ }^{72}$.

Nessas decisões, há a mera referência a princípios colidentes que, então, devem ser submetidos à ponderação. Não é feita qualquer análise acerca da proporcionalidade, a quem essas decisões se referem apenas como um preparatório para anunciar o princípio escolhido.

Ignorado o critério da proporcionalidade, a lei de colisão, que diz o que de fato deve ser fundamentado para se justificar o enunciado de preferência resultado da ponderação é, assim desconsiderada. Senão vejamos, pelos seguintes julgados:

\section{1)}

Pretende a parte autora, a indenização por danos morais em razão de ter que revistar bolsas de mulheres, assim como por ser revistado, tanto por homens, quanto por mulheres. O acionado, em sua defesa, admite a prática de revistas dos pertences de seus empregados, aduzindo, apenas, que era realizada em relação a todos os funcionários e que a revista não era realizada de forma rigorosa ou com excessos, ao ponto de ensejar a ocorrência de dano moral.

A responsabilização do empregador por danos morais demanda a comprovação dos seguintes requisitos: a) do dano - ainda que este se demonstre pelas circunstâncias em que ocorreram os fatos (in re ipsa); b) do ato ilícito ou abusivo; c) do nexo causal entre o dano e a atitude ilícita do agente e; d) da culpa (CC, arts. 186 e 927).

A CRFB tem como fundamentos o princípio da dignidade da pessoa humana e o valor social do trabalho (CFRB, art. $1^{\circ}$, III e IV c/c art. 170), orientando o sistema jurídico para a defesa da personalidade.

72 Partindo desse posicionamento, Alexy ressalta, incessantemente, o caráter extremamente custoso desses direitos para o Estado, chegando até mesmo a questionar a efetiva existência deles como direitos fundamentais. 
Os direitos da personalidade são um conjunto de normas para a proteção da pessoa nos seus aspectos físico e moral, tal qual o direito à vida, à liberdade, à honra, à imagem, à intimidade e à vida privada (CFRB, art. $5^{\circ}, \mathrm{V}$ e X).

Por sua vez, dano moral é a privação ou a diminuição daqueles bens que têm um valor precípuo na vida do homem,como a paz, a tranquilidade de espírito, a liberdade individual, a honra e os demais sentimentos, causando-lhe dor e sofrimento.

O dano moral propriamente dito é aquele que coloca o ofendido em situações humilhantes e constrangedoras perante o seu grupo social e familiar, ocorrendo na esfera subjetiva e alcançando aspectos ligados à personalidade.

No caso vertente, é incontroversa a realização de revistas de bolsas e sacolas pelo empregador, em relação a todos os empregados, inclusive o acionante, assim como a prática de revistas pelo reclamante em relação aos demais funcionários, inclusive mulheres.

Entretanto, para se verificar se estes fatos ensejaram a ocorrência de dano moral é preciso analisar a forma como as revistas eram realizadas.

No caso em comento, a prova oral produzida, inclusive com o reconhecimento do autor em depoimento pessoal, dá conta que as revistas eram feitas apenas de forma "visual", sem que o reclamante "tocasse" ou "fosse tocado" por outro vigia, do sexo masculino ou feminino, assim como sem a necessidade do obreiro "mexer" nos pertences dos demais funcionários.

Ademais, a revista era realizada indistintamente, em relação a todos os funcionários da empresa ré.

É certo que, no presente caso, há a colisão de direitos fundamentais dos indivíduos, sendo, de um lado, os direitos à propriedade e à livre iniciativa do empregador (CRFB, art. 10, $^{\circ}$, IV e art. $5^{\circ}$, XXII) e, de outro, os direitos à intimidade, à honra e à imagem do trabalhador (CRFB, art. $\left.5^{\circ}, \mathbf{X}\right)$. [grifo nosso]

Considerando que não existem direitos fundamentais absolutos e que o exercício do direito encontra limite na atuação do direito dos demais indivíduos, essa colisão de princípios deve ser solucionada com base nos postulados da proporcionalidade e da razoabilidade, através da ponderação de interesses no caso concreto. [grifo nosso]

No caso em comento, não há prova nos autos que o obreiro tenha sido submetido a revistas íntimas, com a ocorrência de situações humilhantes e aviltantes à dignidade da pessoa humana.

Ainda, resta evidente que as revistas eram realizadas em relação a todos os empregados da empresa ré, indistintamente, repito, situação esta que não demonstra nenhum ato discriminatório em relação ao demandante que pudesse ensejar a violação de sua honra. 
Ademais, as revistas de bolsas e sacolas não podem ser consideras "revistas íntimas", vez que, a despeito de trazerem desconforto aos obreiros, não passam de meros "aborrecimentos", não havendo falar em violação à intimidade do indivíduo.

Assim, não tendo sido provada a ocorrência de excessos por parte do empregador, independentemente da existência de outros meios de controle dos quais o réu poderia ter se utilizado em defesa do seu patrimônio, as revistas de bolsas e sacolas e a utilização de detector de metais se justificam, no caso vertente, para a proteção de seu direito à propriedade, razão pela qual não podem ser consideradas imotivadas ou abusivas. [grifo nosso]

Com efeito, considerando os princípios da proporcionalidade e da razoabilidade, tenho que a conduta do empregador, no presente caso, não se insere dentre os fatos passíveis de serem entendidos como prática de dano moral. [grifo nosso]

Não procede o pleito contido no item "c", do pedido. ${ }^{73}$

2)

A proteção à intimidade e à vida privada das pessoas é assegurada pela Constituição da República, por meio do art. $5^{\circ}$, inciso X, correspondendo a um direito fundamental. Ao ingressar numa relação de emprego, o empregado não se despoja de seus direitos fundamentais, que permanecem incólumes e devem ser respeitados pelo empregador, no que se denomina de eficácia horizontal dos direito fundamentais.

Por outro lado, a propriedade privada é garantida pela ordem constitucional, correspondendo igualmente a um direito fundamental (art. $5^{\circ}$, caput e inciso XXII). Havendo colisão entre os direitos fundamentais à intimidade e à propriedade, deve-se proceder a ponderação dos interesses em jogo. [grifo nosso]

Nesse passo, estabelece o art. 373-A, VI, da CLT vedação ao empregador ou preposto de proceder "a revistas intimas nas empregas ou funcionária", ressalvando o caput do mencionado dispositivo "certas especificidades estabelecidas nos acordos trabalhistas". Tal dispositivo, embora esteja incluído no capítulo destinado à proteção ao trabalho da mulher, é aplicável analogicamente aos trabalhadores do sexo masculino, por força do Princípio Constitucional da Isonomia (art. $5^{\circ}$, inciso I, da Carta Magna).

Constata-se, portanto, que o legislador ordinário vedou apenas as revistas íntimas procedidas nos empregados e, ainda assim, abriu a possibilidade de que os entes coletivos pudessem afastar a incidência desta proibição, desde que as especificidades da

\footnotetext{
${ }^{73}$ TRT 19ª Região, RT 0000929-86.2014.5.19.0002, Julgada em 30/03/2014.
} 
categoria assim aconselhassem. Isso significa que no conflito entre a proteção à intimidade do empregado e o direito de propriedade do empregador inexiste prevalência absoluta de um direito o outro.

A realização de revistas pessoais nos empregados não é ilícita, pois "o empregador tem o direito de revistar o empregado, mormente quando estes trabalhem com produtos de valor elevado, entretanto, esse direito que tem o empregador, porquanto somente se abusa do direito que se tem, quando exercido com abuso, desviado o fim social, configura ato ilícito." (Mauro Schiavi, Ações de reparação por danos morais decorrentes da relação de trabalho, LTr, 2008, p. 105).

Contudo, para que a revista não seja tida como abusiva, entende a doutrina que a medida deve ser justificada pela existência na empresa de bens com valor material, suscetíveis de fácil ocultação e subtração, tendo caráter geral, impessoal e objetivo, sendo realizada em local reservado e com respeito aos direitos da personalidade do empregado.

In casu, tenho que o procedimento adotado pela ré atendia a todos esses requisitos, consistindo em exercício regular de direito.

As testemunhas interrogadas por iniciativa empresarial, naquela relação processual, também confirmaram que o procedimento era aleatório, geral e impessoal, além de ser realizado em local reservado, longe dos olhos dos observadores.

\section{$[\ldots]$}

Não havia necessidade de o empregado se despir totalmente, ecoando de forma isolado o depoimento colhido nestes autos, por testemunha indicada pelo autor (fls. 110/111).

Em casos como o dos autos, a revista pessoa há de ser declarada legítima, eis que observados os "procedimentos normais, desenvolvidos com discrição e indiscriminadamente, preservando $o$ devido respeito ao ser humano, não consistindo, consequentemente, em ato abusivo" (TJ-RJ, $1^{\text {a }}$ Câm. Cív., reg. Em 27.09.95 - AP 5.365/94 - Rel. Des. Sérgio Fabião). ${ }^{74}$

$[\ldots]$

\section{3)}

DANO MORAL GENÉRICO. REVISTA MERAMENTE

VISUAL EM BOLSAS E SACOLAS DE TODOS OS EMPREGADOS. PROPRIEDADE VERSUS INTIMIDADE

Há evidente colisão de direitos fundamentais relativos à propriedade e à intimidade na hipótese de revista realizada pelo empregador, em objetos pessoais dos empregados, para preservar o seu patrimônio. [grifo nosso]

74 TRT 6 ${ }^{\text {a }}$ Região, RO 01491-2008-016-06-00-4, Relator Juiz convocado Ibrahin Alves Filho, $1^{\text {a }}$ Turma, Julgado em 18/08/2009, DEJT 20/08/2009. 
Tal procedimento é feito pela necessidade de preservação do empreendimento, no qual há interesse tanto para o empresário quanto para os trabalhadores. Daí, a questão se resolve pela ponderação de interesses entre os princípios constitucionais relativos ao direito de propriedade e à intimidade. [grifo nosso] Assim, por não se revestirem de caráter absoluto, entende-se pela coexistência de

ambos, com a prevalência daquele que se repute melhor a preservar ambos os interesses em conflito, embora com possibilidade de mitigação de um ou ambos.

Daí, plenamente justificável como manifestação do poder diretivo empresarial a mitigação à intimidade dos empregados em grau suficiente a justificar a preservação do empreendimento, o que melhor atende à aos interesses sociais envolvidos.

Nessa senda, esta Corte tem reiteradamente entendido que a mera inspeção visual de bolsas, pastas e sacolas dos empregados, sem contato corporal e ausente qualquer evidência de que o ato possua natureza discriminatória, não é suficiente para, por si só, ensejar reparação por dano moral. Precedentes.

\section{Conhecido e provido. ${ }^{75}$}

\section{4)}

Só se pode considerar revista íntima aquela que implica desnudamento total do trabalhador ou a apalpação do seu corpo. Esta só se justifica, em casos excepcionalíssimos, diante da fundada suspeita do cometimento de algum delito no ambiente de trabalho, como furto, tráfico de drogas, terrorismo, espionagem industrial, sabotagem etc. e ainda, assim, na presença de uma autoridade policial.

Por seu turno, a revista meramente visual, ou seja, a busca feita nas bolsas, mochilas ou sacolas, embora sempre acarrete algum constrangimento, está dentro da esfera do poder diretivo do empregador e da função social da propriedade. A propósito, estes princípios constam do rol dos direitos fundamentais: "Art. $5^{\circ}$ - [...] XXII - é garantido o direito de propriedade; XXIII - a propriedade atenderá a sua função social". Por seu turno, EROS ROBERTO GRAU lembra que a propriedade-função social está prevista Título VII (Da ordem econômica e financeira), em seu Capítulo I (Dos princípios gerais da atividade econômica), no dispositivo seguinte:

Art. 170 - A ordem econômica, fundada na valorização do trabalho humano e na livre iniciativa, tem por fim assegurar a todos existência digna, conforme os ditames da justiça social, observados os seguintes princípios:

75 TST, RR 144100-26.2004.5.02.0067, Relator Ministro Emmanoel Pereira, 5 ${ }^{\text {a }}$ Turma, Julgado em 10/03/2010, DEJT 19/03/2010. 


\section{[...] II - propriedade privada;}

\section{III - função social da propriedade; [...].}

Não se pode deslembrar que a atividade econômica desenvolvida pela empresa é responsável pela geração de emprego e renda, bem como pelo aumento da arrecadação de impostos, a serem revertidos a favor de toda a sociedade.

De tal arte, o empregador tem o direito de proteger não só o seu patrimônio como a integridade física e moral daqueles que trabalham dentro da empresa. A propósito, PINHO PEDREIRA lembra que "o direito à intimidade é erga omnes, e, como todo direito, não possui caráter absoluto. Fica sujeito aos limites da ordem, segurança e saúde públicas".

Assim, entendemos pela legalidade da revista visual do trabalhador, mas dês quando não haja contato físico (toques, apalpadelas) nem acarrete o seu completo desnudamento. Até mesmo porque é consabido que determinadas atividades comerciais propiciam o furto de produtos ou a veiculação de segredos de indústria por parte dos empregados.

Em cada caso concreto se impõe um sopesamento entre os direitos fundamentais da propriedade da empresa do empregador, bem como da vida e segurança daqueles que circulam em suas dependências, com o direito à intimidade do empregado. A propósito, VIRGÍlLIO AFONSO DA SILVA lembra que os direitos fundamentais têm estrutura de princípios, ou seja, são mandamentos de otimização, que, ipso facto, deverão ser, no caso concreto, garantidos na medida do possível; e não na base do "tudo-ou-nada", como se tivessem uma estrutura de regra.

Por seu turno, ALICE MONTEIRO DE BARROS chega à conclusão de que o empregador tem, sim, o direito de revistar os seus empregados, de forma a proteger o seu patrimônio contra furtos, atos de sabotagem ou mesmo de terrorismo. Nada obstante, essa fiscalização deve se dar de forma razoável, por intermédio de sorteio, abarcando todos os trabalhadores da empresa; ou pelo menos todos que trabalhem nos setores mais sensíveis a atos ilícitos.

A posição de MONTEIRO DE BARROS nos parece equilibrada e consoante a teoria dos princípios, visto que procede à ponderação entre os direitos fundamentais de propriedade e de segurança do empregador com o direito à proteção da intimidade do empregado. Assim, o empregador estará exercendo o seu legítimo direito de defesa contra atos de espionagem, sabotagem, furtos, etc. Por outro lado, a proteção da intimidade do empregado, na medida do possível, fica, igualmente, preservada.

Tal posição está afinada com a teoria dos princípios, mais precisamente no que tange ao princípio da proporcionalidade. Por sinal, WILLIS SANTIAGO GUERRA FILHO professa que o princípio da proporcionalidade é um "princípio dos princípios" e ainda que ele "... determina a busca de uma 'solução de compromisso', respeitando-se mais, em determinada situação, um 
dos princípios em conflito, e procurando desrespeitar o mínimo ao(s) outro(s)...".

O princípio da proporcionalidade implica o balanceamento entre os direitos fundamentais a serem protegidos, de modo que seja assegurada a prevalência do bem da vida mais importante entre os dois (ou mais) postos em conflito. O princípio da proporcionalidade mantém estreita relação com o da liberdade, o da igualdade e com o da unidade da Constituição. Isso porque não há hierarquia formal entre os direitos fundamentais e não é admissível uma interpretação capaz de considerar uma norma constitucional contrária a outra da mesma natureza sem pôr em risco a unidade da Lex Legum.

Ao examinar o caso concreto, portanto, o juiz, inspirado pela equidade, pondera os prós e os contras de sua decisão, adotando aquela que melhor se coadune com os valores da Constituição. Assim, o princípio da proporcionalidade é necessário tanto para solucionar o conflito entre direitos fundamentais, postos em jogo num caso real, quanto para a interpretacão da Constituicão. Id est, ele serve à aplicacão e à interpretacãa da norma. [grifo nosso]

Desse modo, "a ponderação resulta indispensável quando o cumprimento de um princípio significa o não cumprimento de outro, isto é, quando um princípio unicamente pode realizar-se a custa de outro". Para esses casos ROBERT ALEXY, com o apoio na jurisprudência do Tribunal Constitucional Federal da Alemanha, formula a seguinte "regra (sic) da ponderação": "Quanto maior seja o grau de não cumprimento ou de afetação de um princípio, tanto maior deve ser a importância do cumprimento de outro".

No caso dos autos, não vislumbramos nenhuma ofensa à privacidade, intimidade ou honra do Obreiro, conforme se infere da prova testemunhal por ele produzida, sendo importante registrar, que não ficou provado que o Reclamante era apalpado durante a revista.

\section{$[\ldots]$}

Conclui-se facilmente que não houve qualquer tipo de excesso, [ grifo nosso] quando do procedimento de vistoria efetuado no Recorrente.

Este Eg. Tribunal tem reiteradamente entendido que a inspeção visual de bolsas e pertences dos empregados, sem contato corporal entre chefia e empregado ou necessidade de despimento, e ausente qualquer evidência de que o ato possua natureza discriminatória, não é suficiente para, por si só, ensejar o pagamento de compensação por dano moral.

Com efeito, não há falar em ofensa ao princípio da dignidade da pessoa humana ou à presunção geral de inocência, porquanto o ato empresarial revela exercício regular de proteção de seu patrimônio, que, por seu caráter generalizado, é incapaz de acarretar constrangimento ou lesão à privacidade dos inspecionados. 
Dou provimento para excluir da condenação o pagamento de indenização por danos morais $(\mathrm{R} \$ 10.000,00)$ decorrentes da revista visual. ${ }^{76}$

Há, ainda, decisões que desconsideram o efeito da existência de uma regra tratando da matéria, passando esses julgados à realização de sua ponderação:

\section{DANOS MORAIS. REVISTA ÍNTIMA. EMPRESA DE PRODUTOS FARMACÊUTICOS}

O Tribunal Regional negou provimento ao recurso ordinário interposto pela Reclamada e manteve a sentença, na qual se condenou a Reclamada ao pagamento de indenização por danos morais no "importe de $R \$ 40.000,00$ (quarenta mil reais), com incidência de juros e correção monetária". Consignou que a Reclamada expôs o Autor a situação vexatória e humilhante e entendeu que a conduta praticada é "flagrantemente atentatória à dignidade do empregado que é obrigado a se despir perante outros funcionários para provar que 'não cometeu' qualquer ilicitude na empresa". Registrou que a Reclamada descumpriu o termo de ajuste de conduta firmado perante o Ministério Público do Trabalho, em que se comprometeu a "abster-se 'de realizar revistas intimas em seus empregados"'. Considerou que "ser obrigado a desnudar-se, quando se está na condição de subordinação jurídica (hipossuficiência) é um absurdo inominável" e "verdadeiro abuso de poder por parte do empregador, sendo ainda mais grave tal fato quando se trata de empresa que já havia firmado compromisso com o Ministério Público do Trabalho". Concluiu que cabe à Reclamada "adequarse ao termo de ajuste de conduta, investindo em outros meios de segurança e controle que não afetem o empregado ou não o exponham a tais situações" e que "é flagrante o dano moral, estando presentes não só a tipificação do ato ilícito como a comprovação induvidosa do prejuízo moral causado pelo empregador, justificando-se a fixação de indenização capaz de minorar ou compensar a lesão provocada".

A matéria discutida nos autos demanda a necessidade de se averiguar se a revista íntima era necessária, justa e adequada a fim de evitar o desvio de substâncias entorpecentes e psicotrópicas. [grifos nossos]

Consta do acórdão recorrido que a razão social da Reclamada é Distribuidora Farmacêutica Panarello Ltda..

\section{$[\ldots]$}

76 TST, RR 977-86.2011.5.05.0019, Relator Desembargador convocado João Pedro Silvestrin, $8^{\mathrm{a}}$ Turma, Julgado em 11/06/14, DELT 13/06/14. 
É fato público e notório que a venda de remédios passa por rigoroso controle dos órgãos fiscalizadores da vigilância sanitária e do Ministério da Saúde, haja vista as consequências nocivas que o uso indevido de tais medicações pode causar às pessoas.

Portanto, a Recorrente deve cercar-se de todos os cuidados para impedir desvio dos produtos comercializados, pois tal controle não visa apenas a resguardar o patrimônio do empregador, mas, acima de tudo, busca defender matéria de interesse da coletividade, diante da natureza da atividade exercida pela Recorrente.

Diante disso, observa-se um aparente conflito de direitos fundamentais. De um lado, o direito dos empregados em ter garantida sua privacidade e intimidade, previsto no art. $5^{\circ}, X$, da Constituição da República. De outro lado, a necessidade de preservação da segurança da coletividade, consagrada no caput do art. $5^{\circ}$ da $\mathrm{CF} / 88$.

A doutrina caracteriza o direito à privacidade nos seguintes termos:

"A reclusão periódica à vida privada é uma necessidade de todo homem, para a sua própria saúde mental. Além disso, sem privacidade, não há condições propícias para o desenvolvimento livre da personalidade. Estar submetido ao constante crivo da observação alheia dificulta o enfrentamento de novos desafios. A exposição diuturna dos nossos erros, dificuldades e fracassos à crítica e à curiosidade permanentes de terceiros, e ao ridículo público mesmo inibiria toda tentativa de autossuperação. Sem a tranquilidade emocional que se pode auferir da privacidade, não há muito menos como o indivíduo se autoavaliar, medir perspectivas e traçar metas" (MENDES, Gilmar Ferreira \& BRANCO, Paulo Gustavo Gonet. Curso de Direito Constitucional. 6 ${ }^{\mathrm{a}}$ Ed. São Paulo: Saraiva, 2011. pp. 315/316 - destaques acrescidos).

Pelo que se percebe, o direito à preservação da privacidade e da vida íntima representa uma prerrogativa da mais alta relevância no ordenamento jurídico e garante aos indivíduos a proteção de suas relações familiares e também do respeito ao aspecto íntimo inerente a todo ser humano.

No Direito do Trabalho, essa característica se coaduna com a proteção ao trabalhador contra arbitrariedades perpetradas pelo empregador, especialmente quando se trata do abuso do poder diretivo previsto no art. $2^{\circ}$ da CLT.

Entretanto, o direito à intimidade não tem caráter absoluto. Ao revés, a característica precípua dos direitos fundamentais revela que podem ser objeto de limitações. Nas palavras do Excelentíssimo Ministro do Supremo Tribunal Federal Gilmar Ferreira Mendes:

"Tornou-se pacífico que os direitos fundamentais podem sofrer limitações, quando enfrentam outros valores de ordem constitucional, inclusive outros direitos fundamentais. Prieto Sanchis noticia que a afirmação de que 'não existem direitos ilimitados se converteu quase em cláusula de estilo na 
jurisprudência de todos os tribunais competentes em matéria de direitos humanos'.

Igualmente no âmbito internacional, as declarações de direitos humanos admitem expressamente limitações 'que sejam necessárias para proteger a segurança, a ordem, a saúde ou a moral pública ou os direitos e liberdades fundamentais de outros'.

A leitura da Constituição brasileira mostra que essas limitações são, às vezes, expressamente previstas no Texto. Até o elementar direito à vida tem limitação explícita no inciso XLVII, $a$, do art. $5^{\circ}$, em que se contempla a pena de morte em caso de guerra formalmente declarada.

Não há, portanto, em princípio, que falar, entre nós, em direitos absolutos. Tanto outros direitos fundamentais como outros valores com sede constitucional podem limitá-los" (op. cit. pp. 162/163 - destaques acrescidos).

Conforme o exposto, percebe-se que até mesmo os direitos fundamentais, constitucionalmente previstos, são suscetíveis a limitações, que devem ser analisadas de acordo com a circunstância em concreto.

No caso em análise, deve-se ressaltar que a atuação da empresa Recorrente, consistente em proceder à revista íntima de todos os seus empregados, assenta-se no fato de que o material produzido tem características químicas cuja utilização, sem o devido acompanhamento médico, pode acarretar diversos danos à saúde e à coletividade. Portanto, existe interesse coletivo que mitiga o direito de intimidade dos empregados.

Esta Turma já manifestou entendimento de que a revista íntima, realizada sem excessos ou abusos, prevalece ao direito de intimidade do empregado, quando existir interesse público relativo à segurança da sociedade. [grifo nosso]. Nesse sentido:

"RECURSO DE REVISTA. REVISTA ÍNTIMA. AGENTE
DE DISCIPLINA DE PRESÍDIO. PRINCÍPIO DA
PROPORCIONALIDADE. RELAÇÕES ESPECIAIS DE
SUJEIÇÃO. PREVALENCIA DO DO INTERESSE COLETIVO. DANOS MORAIS INEXISTENTES. I. As premissas fáticas consignadas pelo Regional e, portanto, imutáveis nesta esfera (Súmula 126) foram: a) o Autor, como agente de disciplina trabalhando em presídio, era submetido a revista íntima onde tinha de se desnudar, agachar três vezes e abrir a boca botando a língua para fora; b) essa revista era feita em uma sala fechada, perante dois colegas que deixavam o turno e era de pleno conhecimento do Autor desde o curso preparatório para o ingresso na função; c) o próprio Autor ao deixar o turno também vistoriava os que entravam para lhe render; d) o detector de metais e aparelho raio-x que havia no presídio não se prestavam a detectar a entrada de droga. II. Nesse panorama, a questão que se coloca é se a pretexto da defesa da segurança ou de um interesse coletivo, a intimidade de um indivíduo, direito fundamental, pode ser afrontada na forma como acima foi exposta. Os direitos fundamentais, que se assentam na própria Constituição da República, podem sofrer limitação quando estiver em jogo a 
necessidade de se viabilizar o funcionamento adequado de certas instituições - são as situações chamadas de relações especiais de sujeição. É o princípio da proporcionalidade que vai traçar a legalidade ou não de determinada conduta quando estiver na balança esta mesma conduta em oposição a um direito fundamental individual. $\mathrm{E}$ as dimensões do princípio da proporcionalidade têm sido pontuadas pela doutrina (a partir de decisões da Corte Constitucional alemã) em três critérios: a adequação, a necessidade ou vedação de excesso e de insuficiência e a proporcionalidade em sentido estrito. Estando presentes estes três critérios, há possibilidade de se limitar um direito fundamental. III. Do que ficou assentado, a revista era necessária porque o raio-x não detectava a entrada de drogas no presídio. Portanto, nem o detector de metais nem o aparelho de raio-x poderiam substituir a revista que era procedida. Ademais, extraise, com facilidade, do acórdão regional, que o motivo que ensejou a adoção do procedimento ora questionado foi exatamente a inadequação da aparelhagem para coibir a entrada de drogas no presídio. A revista íntima procedida foi adequada e a possível para atingir o resultado que se pretendia, isto é, não permitir a entrada de drogas no presídio. IV. Não há de se questionar que a revista a que eram submetidos os empregados da Reclamada enquanto agentes de disciplina era no mínimo constrangedora. $\mathrm{O}$ que se deve perquirir é se havia maneira menos onerosa moralmente para se evitar que a fiscalização para coibir a entrada de drogas fosse realizada dessa forma. E, aqui, há de se considerar que a Reclamada prestava serviço a uma penitenciária do estado que, portanto, era quem disponibilizava os meios de fiscalização. E esses meios, detector de metais e aparelho de raio-x, não permitiam que se averiguasse a entrada de drogas, porque eram ineficazes. Ademais, à época, não havia mesmo outro meio mais suave ou menos constrangedor para se atingir o fim pretendido. V. Por fim, ainda resta analisar o último viés do princípio da proporcionalidade: o benefício alcançado pela revista íntima buscou preservar valores mais importantes do que os protegidos pelo direito que tal medida limitou? $\mathrm{E}$ a resposta a esta última indagação exsurge cristalina no sentido afirmativo, porque o objetivo da revista era nada menos do que garantir a segurança dos presídios, em benefício de toda a população, inclusive dos que ali trabalham. A razão pública aqui suplanta a limitação da intimidade do Autor. Violações não configuradas. Recurso de Revista não conhecido" (RR - 2800010.2009.5.11.0019 Data de Julgamento: 03/08/2011, Relatora Ministra: Maria de Assis Calsing, 4 ${ }^{\mathrm{a}}$ Turma, Data de Publicação: DEJT 12/08/2011)".

Além disso, os doutrinadores preveem no poder de comando da atividade empresarial a possibilidade do uso de revistas pessoais nos empregados, desde que tal procedimento não exceda os limites de razoabilidade. Nesses termos, é a lição de Irany Ferrari e Melchíades Rodrigues Martins, que está assim redigida:

"Outros exemplos mais frequentes dizem respeito ao direito do empregador de proceder às revistas de seus empregados durante a jornada de trabalho ou na saída do estabelecimento.

Não há dúvida de que esse direito enquadra-se no poder diretivo do empregador, que é uma forma de controlar seu patrimônio. 
Tais revistas devem, contudo, ser realizadas sem ferir a dignidade do empregado, sua imagem e seu conceito junto aos demais empregados, seus colegas. Para tanto, será preciso que as revistas sejam feitas com critério de bom senso e prudência, de modo a que as mulheres sejam revistadas por mulheres e homens, sem agressões e sem exposições a vexames ou malestares.

Por outro lado, as revistas devem ter um cunho geral (do estabelecimento ou determinados setores de trabalho), de modo que se evitem discricionariedade ou perseguições" (Dano Moral: múltiplos aspectos nas relações de trabalho - comentários, referências legais, bibliografia e jurisprudência. São Paulo: LTr, 2005. p. 423).

No mesmo sentido, é a jurisprudência desta Corte Superior:

"DANO MORAL. REVISTA ÍNTIMA. INEXISTÊNCIA. PROVIMENTO. Restou delimitado no v. acórdão regional que a revista aos empregados se dava de forma moderada, sem contato físico e sem exposição dos empregados. Assim, a revista não constitui por si só, motivo a provar o constrangimento, nem violação da intimidade da pessoa, tampouco discriminação, visto que revista era realizada de forma impessoal, razão por que indevida a indenização por dano moral. Recurso de Revista conhecido e provido" (RR - 540400-41.2007.5.09.0660 Data de Julgamento: 23/09/2009, Relator Ministro Aloysio Corrêa da Veiga, 6 Turma, Data de Publicação: DEJT 09/10/2009).

"DANO MORAL. REVISTA ÍNTIMA. AUSÊNCIA. O exercício do poder diretivo não constituirá abuso de direito quando não evidenciados excessos praticados pelo empregador ou seus prepostos. A tipificação do dano, em tal caso, exigirá a adoção, por parte da empresa, de procedimentos que levem o trabalhador a sofrimentos superiores aos que a situação posta em exame, sob condições razoáveis, provocaria. A moderada revista, se não acompanhada de atitudes que exponham a intimidade do empregado ou que venham a ofender publicamente o seu direito à privacidade, não induz à caracterização de dano moral. Recurso de revista não conhecido" (ARR - 955300-94.2009.5.09.0012 Data de Julgamento: 16/11/2011, Relator Ministro: Alberto Luiz Bresciani de Fontan Pereira, $3^{\text {a }}$ Turma, Data de Publicação: DEJT $18 / 11 / 2011)$

Noutro passo, não consta do acórdão qualquer indício de que as revistas eram efetuadas de forma vexatória. É verdade que, de acordo com a decisão recorrida, os empregados despiam os uniformes e ficavam "só de cueca, passando pela vistoria sem baixar a cueca" (fl. 292) e que tal situação gera certo desconforto para os trabalhadores. Entretanto, o Tribunal Regional não apontou nenhum elemento capaz de demonstrar que as revistas reduziam a honra do Autor, ou até mesmo que os prepostos da empresa Recorrente agiam de forma jocosa durante o procedimento de revista, capaz de extrapolar os limites do poder de direção.

Portanto, não se verifica ato suficientemente capaz de ensejar a ocorrência de dano à imagem e à moral do empregado e, por conseguinte, de autorizar a condenação ao pagamento de indenização. 
Diante do exposto, dou provimento ao recurso de revista interposto pela Reclamada, para excluir da condenação o pagamento de indenização por danos morais no importe de $\mathrm{R} \$$ $40.000,00$ (quarenta mil reais). ${ }^{77}$

Tal exercício ponderativo, como descrito acima, ou seja, entre uma regra e um princípio - não teria lugar na teoria de Alexy, vez que, para o referido autor, se uma regra é clara, sem que seja estabelecida uma cláusula de exceção, está pressuposto no processo de sua elaboração que o legislador já fez as ponderações necessárias e já determinou o valor a ser preservado.

Questão problemática, segundo Virgílio Afonso da Silva,

\begin{abstract}
uma vez que dá a entender que o aplicador do direito está sempre livre, em qualquer caso e em qualquer situação para afastar a aplicação de uma regra por entender que há um princípio mais importante que justifica esse afastamento. Isso teria como consequência um alto grau de insegurança jurídica. Um dos papéis mais importantes das regras é justamente aumentar o grau de segurança na aplicação do direito. Essa segurança é garantida quando uma instância tem a competência de definir uma determinada linha. Essa instância, em um Estado constitucional, é o legislador., e essa linha é definida pelas regras que ele cria. Esse é um ponto que é muitas vezes ignorado quando se pensa em colisão entre regras e princípios. Em geral, não se pode falar em uma colisão propriamente dita. $\underline{\mathbf{O} \text { que há é simplesmente o }}$ produto de um sopesamento, feito pelo legislador, entre dois princípios que garantam direitos fundamentais, e cujo resultado é uma regra de direito ordinário. A relação entre a regra e um dos princípios não é, portanto, uma relação de colisão, mas uma relação de restrição. A regra é a expressão dessa restrição. Essa regra deve, portanto, ser simplismente aplicada por

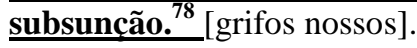

Assim, a decisão analisada vai de encontro à toda a construção doutrinária de Alexy nesse sentido e admite a revista íntima em empresas de medicamentos e em presídios, desconsiderando a existência de lei vedando sua prática, sem qualquer restrição, fruto de um sopesamento já realizado pelo legislador desde $1999^{79}$. No caso da revista

77 TST, RR 162400-53.2005.5.006.0014, Relator Ministro Fernando Eizo Ono, , $4^{a}$ Turma, Julgado em 14/12/11, DEJT 10/02/12.

${ }^{78}$ SILVA, Virgílio Afonso da. Direitos fundamentais. Conteúdo essencial, restrições e eficácia. 2.ed. São Paulo: Malheiros, 2011.p.52.

${ }^{79}$ Artigo 373-A dispõe ser vedado, em seu inciso "VI - proceder o empregador ou preposto a revistas íntimas nas empregadas ou funcionárias." 
íntima realizada em estabelecimento prisional, chegam mesmo a declinar todo o exercício da máxima da proporcionalidade, exercendo ponderação onde não é dado fazê-lo.

Do exposto, resulta claro que ainda que os julgados analisados digam estar se utilizando do Pós-positivismo de Alexy, disso não se trata. Não estamos aqui a defender que, utilizada de forma correta, referida doutrina seria viável à efetivação dos direitos fundamentais sociais e, assim, à concretização do Direito do Trabalho. Mas, por sinceridade metodológica, cumpre desvendar que, em verdade, não se utilizam do póspositivismo tal como preconizado na obra em que dizem se basear. 


\title{
CAPÍTULO 3
}

\section{INAPLICABILIDADE DA TEORIA DE ALEXY AO DIREITO DO TRABALHO}

\author{
"A crítica arrancou as flores imaginárias \\ dos grilhões, não para que os homens os \\ suportem sem fantasias ou consolo, mas \\ para que lance fora os grilhões e a flor \\ viva brote."
}

- Karl Marx

\author{
"Não creio em solução para o \\ Direito do Trabalho que não \\ avance para frente, em direção \\ ao trabalhador."
}

- Marcio Tulio Viana

Como procuramos demonstrar no capítulo anterior, as decisões trabalhistas colacionadas não tratam do Pós-positivismo de Robert Alexy, muito embora a ela se refiram expressamente como argumento em suas respectivas fundamentações.

Neste capítulo, demonstraremos que, ainda que referida teoria fosse utilizada segundo os preceitos de Alexy, ela própria seria inaplicável ao Direito do Trabalho, e isso em razão de sua construção histórica.

De fato, não há como se compreender a técnica jurídica trabalhista, com todo seu arcabouço principiológico, sem conhecer o histórico de sua origem e consolidação. 
Buscado essa compreensão, o primeiro dado a reconhecer é que o direito laboral é uma decorrência do modelo de produção capitalista ${ }^{80}$. A experiência concreta de um Direito do Trabalho em nível mundial começa a surgir, ainda de forma incipiente, na segunda metade do século XIX, dentro de um contexto em que se insere, também, a tomada de consciência dos trabalhadores em torno das características econômicas e políticas da exploração da mão-de-obra, conduzida, pela lógica da concorrência internacional instaurada, a níveis insuportáveis para a condição humana e, também, o próprio temor da classe burguesa quanto aos possíveis sucessos da organização e dos movimentos revolucionários dos trabalhadores.

Daí, por certo, a própria natureza paradoxal do Direito do Trabalho

\begin{abstract}
O direito do trabalho surge, então, como fórmula da classe burguesa para impedir a emancipação da classe operária. Com o direito do trabalho, a separação de classes se mantém. Todavia, paradoxalmente, com o surgimento do direito do trabalho, inicia-se um processo de valorização do trabalho que somente foi possível a partir da formação de uma consciência social em torno da necessidade dessa valorização. ${ }^{81}$
\end{abstract}

Nesse sentido também alerta Grijalbo Coutinho:

\begin{abstract}
É inegável que o Direito do Trabalho, num primeiro momento, foi admitido pela burguesia como medida capaz de frear o movimento emancipatório do proletariado, conduzido pela revolução socialista apregoada por Marx, cujo movimento ganhou força na expressão do sentido figurado de oferecer a classe dominante os anéis para se preservar os dedos. Por outro lado, não se pode afirmar que o Direito do Trabalho seja contra a emancipação do proletariado[...], em qualquer movimento reivindicatório de trabalhadores haverá sempre uma pauta ligada às condições dignas de trabalho. ${ }^{82}$
\end{abstract}

Incapaz de lidar com as questões sociais que se lhe apresentam, o Estado liberal assiste, então, a todo o desenrolar da Primeira Guerra Mundial que acarreta, ao final, a pactuação do Tratado de Versalhes, no qual se estabeleceram os princípios que

${ }^{80}$ Conforme pontua José Martins Catharino: "Falar-se em Direito do Trabalho na Antiguidade, na Idade Média, e mesmo antes do século XVIII, não é verdadeiro. É falar-se na sua pré-história, de passado longínquo, quando sequer poderia ser imaginado". In CATHARINO, José Martins. Compêndio de Direito do Trabalho. V.I. 2.ed. São Paulo: Saraiva. p.3.

${ }^{81}$ SOUTO MAIOR, Jorge Luiz. O direito do trabalho como instrumento de justiça social. São Paulo: LTr, 2000, p.70.

${ }^{82}$ COUTINHO, Grijalbo Fernandes. O direito do trabalho flexibilizado por FHC e Lula. São Paulo: LTr, 2009 , p.28. 
deveriam reger as relações trabalhistas, assim como a criação da Organização Internacional do Trabalho, que foi um passo de extrema importância para o reconhecimento dos trabalhadores como classe social e política, sobretudo por conta da sua integração ao órgão deliberativo da referida Organização.

Consignou-se, então, a máxima de que o trabalho não é mera mercadoria de comércio, proclamando-se, também, a necessidade de que todos os países se preocupassem em estabelecer padrões mínimos de convivência entre o capital e o trabalho, buscando atingir a justiça social. Na Constituição da OIT afirmou-se que:

\section{Considerando que a paz para ser universal e duradoura deve assentar sobre a justica social;}

Considerando que existem condicões de trabalho que implicam, para um grande número de indivíduos, miséria e privacões, e que o descontentamento que daí decorre põe em perigo a paz e a harmonia universais, e considerando que é urgente melhorar essas condicões no que se refere, por exemplo, à regulamentação das horas de trabalho, a fixação de uma duração máxima do dia e da semana de trabalho, ao recrutamento da mão-de-obra, à luta contra o desemprego, à garantia de um salário que assegure condições de existência convenientes, à proteção dos trabalhadores contra moléstias graves ou profissionais e os acidentes do trabalho, à proteção das crianças, dos adolescentes e das mulheres, às pensões de velhice e de invalidez, à defesa dos interesses dos trabalhadores empregados no estrangeiro, à afirmação do princípio do princípio "para igual trabalho, mesmo salário", à afirmação do princípio da liberdade sindical, à organização do ensino profissional e técnico, e outras medidas análogas.

Consolida-se no instrumento supra toda a racionalidade desenvolvida até então, ou seja, a constatação de que era necessária a fixação de limites humanísticos ao capitalismo sem rédeas, atentando-se para a realidade de que em meio a toda aquela produção desenfreada de lucros para poucos se encontravam seres humanos, cujas necessidades básicas deveriam ser garantidas. A justiça social, assim, aparece como condição vital à preservação da paz mundial, alçando o Direito do Trabalho e os direitos sociais em geral ao importante status de instrumento para organização do todo social ${ }^{84}$.

\footnotetext{
${ }^{83}$ Constituição da OIT. In

<http://www.oitbrasil.org.br/sites/default/files/topic/decent_work/doc/constituicao_oit_538.pdf >. Acesso em 21/05/2015.

84 "Diante dessa triste situação do operariado, sujeito à bruteza do salário mínimo, fôrça é convir que o direito tem de se modificar, e que a função do Estado ou dos governos, ou dos podêres públicos (como queiram dizer) tem de se transformar; não basta a tutela nem a expectação; é necessário intervir por meios legislativos, no sentido de ser efetivamente melhorada a posição econômica do homem assalariado; é
} 
O Direito do Trabalho, então, advém do pacto firmado pela humanidade no sentido de que o capitalismo só se justifica se calcado nas premissas de promoção de justiça social, buscando a melhoria da condição social do trabalhador e a preservação de sua dignidade humana.

A falta de seriedade de alguns países para com os compromissos assumidos acima, contudo, acaba fazendo com que os problemas identificados antes da $1^{\text {a }}$ Guerra, notadamente no aspecto da relação capital-trabalho, sequer fossem amenizados, o que motivou a eclosão da $2^{\mathrm{a}}$ Guerra. Ao final desta, os países compreendem ainda mais a necessidade de tornarem efetivos os preceitos fixados no Tratado de Versalhes, sendo que para tanto começam pela elevação da OIT a membro da Organização das Nações Unidas, sem deixar de realçar, mais uma vez, a relevância das políticas de distribuição de renda e da promoção de condições dignas de trabalho.

Desse modo, o consenso mundial, dos países que se mantiveram fiéis ao capitalismo, foi no sentido de que esse modelo de sociedade somente seria viável com a necessária aplicação da legislação social, para impor limites à lógica do capital.

Reafirma-se o compromisso de que era preciso impor limites aos interesses econômicos, promovendo valores como a solidariedade, que deixa o campo da moral para integrar o texto das Constituições de diversos países, transformando em norma a preocupação social e econômica, dos seres humanos, uns com os outros.

Constata-se a total inviabilidade da crença que se tinha, dentro do contexto da ordem jurídica liberal, de que o capitalismo poderia, naturalmente, ou seja, sem qualquer regulação, gerar paz e justiça para a sociedade.

O Direito Social é, assim, fruto do próprio modelo capitalista, e parte do reconhecimento das injustiças por ele produzidas, buscando impor-lhe limites a fim de mantê-lo vigente.

preciso regular as condições de trabalho, dando satisfação às necessidades humanas do trabalhador. In MORAES, Evaristo de. Apontamentos de direito operário. 4.ed. 1998, p.15. 
Surge, assim, como uma própria evolução do Direito Liberal ${ }^{85}$, suplantando os valores puramente egoísticos voltados à satisfação de interesses econômicos, sendo certo que o modelo de sociedade calcado nesses interesses havia fracassado.

Esse novo estágio, assim, não surge do nada, como um direito destacado do Direito Civil, ideologia que visa apenas considerá-lo um direito de menor importância, com normas meramente programáticas. É, sim, fruto do fenômeno de socialização do Direito como um todo ${ }^{86}$.

[...] o Direito que resulta de uma nova racionalidade para os problema do mundo, onde impera o capital, deve ser o Direito Social, o qual resta no topo do conjunto normativo como um conceito fundamental, tendo como objetivos: buscar a justiça social, efetivar a democracia e proporcionar a internacionalização dos valores sociais inscritos como condição para a paz mundial. No novo Direito impera a concepção de um regramento que por consequência a melhoria da posição da condição humana. Esse é o Direito que se denomina Direito Social por contraposição daquilo que lhe é antecedente, o Direito Liberal, no qual a liberdade, a igualdade, o individualismo conduzem apenas a uma proposição de que as pessoas estão livres para a busca de uma satisfação pessoal fora de qualquer contexto coletivo (se a felicidade, sem correlacionamentos pessoais fosse de fato possível). ${ }^{87}$ [grifos nossos].

Resulta claro, assim, que a própria história da formação do Direito do Trabalho já indica a existência de um processo de ponderação de valores que pendeu para a afirmação da fundamentalidade da proteção do trabalhador como pedra de toque da superação da racionalidade liberal e origem do Direito do Trabalho como um ramo jurídico autônomo. Não há, pois, como criar nova ponderação sobre as normas trabalhistas, que tenham por efeito gerar a fragilidade no objetivo primordial do Direito do Trabalho de

\footnotetext{
85 "O direito social lato sensu se caracteriza pelo fato de considerar "o homem concreto e socializado" e não apenas o "indivíduo despersonalizado e abstrato" de acôrdo com a concepção individualista." In CESARINO JR. , A.F. Direito social brasileiro. 6.ed. São Paulo: Saraiva, 1970, p.8.

${ }^{86}$ "Recordando a justa e conhecida metáfora de Radbruch, de que as árvores não deixavam que se visse o bosque, referindo-se ao individualismo, o Direito do trabalho a este muito se opõe, daí dizer-se ser "social", adjetivo historicamente correto, antitético ao "individual. [...] toda a ordem jurídica se está socializando, fenômeno favorável a uma maior consistência unitária do Direito, alimentada pela crescente convergência dos seus vários ramos, como, p.ex., entre o Direito Civil e o Direito do Trabalho." In CATHARINO, José Martins. Compêndio de Direito do Trabalho. V.I. 3.ed.São Paulo: Saraiva, 1982, p.33.

${ }^{87}$ SOUTO MAIOR, Jorge Luiz. Curso de Direito do Trabalho. Teoria Geral do Direito do Trabalho. Vol.1.Parte 1. São Paulo: LTr, 2011.p.585
} 
promover uma constante melhoria da condição social do trabalhador e a elevação de sua dignidade humana ${ }^{88}$.

Desse modo, exercícios de ponderação feitos pelo julgador que propiciem resultados contrários a essa principiologia estão fora das possibilidades de seu âmbito de atuação, representando, pois, mais do que uma opção equivocada, um erro técnico, além de constituir uma autêntica traição à racionalidade que se procurou consagrar após a vivência de duas guerras mundiais.

\section{Com efeito,}

quando se fala em um direito, que fora especificamente criado com o
objetivo de inibir as injustiças provocadas pela desigualdade
negocial entre trabalhadores e empresários, como ocorreu com o
direito do trabalho, a própria sobrevivência desse direito como ramo
jurídico autônomo está condicionada à preservação de seu princípio
básico, qual seja, a preocupação com a justiça social. Um direito do
trabalho, que na aplicação concreta, produza resultados injustos,
perde plenamente o seu sentido. ${ }^{89}$

O Direito do Trabalho, como um direito social, não é apenas um conjunto de normas que pode ser aplicado ao alvedrio do intérprete, mas a única racionalidade possível, frente o projeto de sociedade adotado. Descumpri-lo por meio de raciocínios de ponderação implicaria a quebra desse projeto, sem nada colocar em seu lugar.

Desse modo, a aplicação de teorias como a ora estudada nas sendas do Direito do Trabalho implica, em última análise, a reprodução de um sistema que não deu certo, ainda que tal não se admita expressamente. Em sentido contrário à racionalidade juslaboral, no sentido de produzir justiça social dentro de um sistema capitalista, aprofundam-se as desigualdades desse sistema, que passa a correr livremente, sem o freio de uma legislação social e sem que se apresente um projeto alternativo de sociedade. ${ }^{90}$

Sem qualquer proposição valorativa ou consciência histórica, a ponderação se reduz, assim, a um mero jogo de palavras, porta aberta à invasão de valores privatísticos superados historicamente e, pior, com a chancela do Poder Judiciário Trabalhista.

88 "A concepção individualista desaparece ante a socialização, como instrumento de justiça social, solidariedade humana e felicidade coletiva." In CESARINO JR., A.F. Direito social brasileiro. 6.ed. São Paulo: Saraiva, 1970,p.26.

${ }^{89}$ SOUTO MAIOR, Jorge Luiz. O direito do trabalho como instrumento de justiça social. São Paulo: LTr, 2000. p.251.

${ }^{90}$ SOUTO MAIOR, Jorge Luiz. Curso de Direito do Trabalho. A relação de emprego. v.II. São Paulo: LTr, 2008.p. 49. 
Conforme afirma, categoricamente, Luís Prieto Sanchís,

[...] donde sí ha de existir equilibrio es en el plano abstracto: en principio, han de ser todos del mismo valor, pues de otro modo no habría nada que ponderar; sencillamente, en caso de conflicto se impondría el de más valor. Ponderar es, pues, buscar la mejor decisión (la mejor sentencia, por ejemplo) cuando en la argumentación concurren razones justificatorias conflictivas y del mismo valor. $^{91}$

Desse modo, não há que se ponderar direito de propriedade com direitos sociais, pois tais princípios não possuem os mesmos valores historicamente concebidos. Iria, assim, contra a própria história humana, ignorando a superação do Direito meramente liberal pelo Direito Social.

Todavia, da análise das decisões colacionadas, vê-se que o juiz, "ao analisar o caso concreto, inspirado pela equidade, pondera os prós e os contras de sua decisão, adotando aquela que melhor se coadune com os valores da Constituição", "assegurando a prevalência do bem da vida mais importante entre os dois postos em conflito" ${ }^{92}$ e, pela opção que faz, é a propriedade, em detrimento do ser humano, o bem da vida mais importante, em nítida afronta à toda construção histórica do Direito do Trabalho.

Isso porque a efetivação dos direitos sociais não constitui mera alternativa dada ao intérprete. Diante de sua formação histórica, a negação de seus preceitos fundamentais constitui verdadeiro retrocesso social, este entendido não como propugnado pela doutrina tradicional e direcionado ao legislador, primordialmente ${ }^{93}$, mas como orientador do raciocínio, em se tratando de direitos sociais, impondo a análise da realidade social a partir do ponto já alcançado pelas experiências passadas, em respeito ao próprio sentido histórico do Direito.

Não se trata de empecilho criado à liberdade de pensamento ou de expressão, mas a consciência de que há de ser estabelecido algum parâmetro de validade aos argumentos trazidos à discussão.

91 SANCHÍS, Luís Prieto. Neoconstitucionalismo y poderación judicial. In: Direitos humanos e globalização: fundamentos desde a teoria crítica. Rio de Janeiro: Lumen juris, 2004, p.400-435.

92 Julgado TST-RR-977-96.2011.5.05.0019.

${ }^{93}$ Segundo Luís Roberto Barroso, "trata-se de um princípio, que não é expresso, mas decorre do sistema jurídico-constitucional; entende-se que se uma lei, ao regulamentar um mandamento constitucional, instituir determinado direito, ele se incorpora ao patrimônio jurídico da cidadania e não pode ser absolutamente suprimido". In BARROSO, Luís Roberto. $O$ direito constitucional e a efetividade de suas normas. 5.ed. Rio de Janeiro: Renovar, 2001. p.158. 
Nos dias atuais, por exemplo, é fora de questão e, portanto, fora de qualquer parâmetro válido de argumentação, a defesa da escravidão. Desse modo, ninguém é livre para defender a escravidão, como ninguém o será para defender qualquer tipo de discriminação ou de preconceito racial. Trata-se de pensamentos que, se existirem, não merecem sequer uma contraposição, já que estão fora da racionalidade humana adquirida pelas experiências vividas pela humanidade ${ }^{94}$.

Assim, não há como preservar o capitalismo com base em premissas como a alegação de crise econômica, de exercício de um poder diretivo ilimitado que lhe permite, inclusive, a realização de revistas. A ponderação que legitima referida conclusão comete uma traição histórica com o que já foi construído teoricamente até hoje e não há crise ou necessidade de preservação da empresa que altere essa racionalidade, ou seja, se o capitalismo tiver que, de fato, dar certo, a base já está posta, qual seja, a preservação da dignidade do trabalhador.

Em outras palavras, se em razão de dificuldades estruturais de ordem econômica, tivermos que sacrificar algum valor jurídico, este não pode ser o Direito Social, vez que constitui o sustentáculo do próprio modo capitalista de produção. Constatado, então, que o custo dos direitos sociais não são suportados pela economia, é esta que tem que ser posta em xeque.

A ponderação, ao negar direitos fundamentais dos trabalhadores, dando prevalência à manutenção da empresa, que para sobreviver requer o descumprimento de direitos trabalhistas, compõe, assim, mais uma forma de retórica de desconstrução dos direitos sociais, nos mesmos moldes daqueles que defendem que esses direitos constituem um estímulo ao desemprego, passando-se por cima de toda a efetivação dos direitos sociais da forma mais natural do mundo, tal qual a "pejotização" do trabalhador, a terceirização, as cooperativas fraudulentas ${ }^{95}$.

Como nos revela Agostinho Ramalho Marques Neto,

Dentro do contexto antes delineado, os princípios, categorias, institutos, conceitos fundamentais e a própria estrutura da lógica

\footnotetext{
${ }^{94}$ SOUTO MAIOR, Jorge Luiz. Curso de Direito do Trabalho. Teoria Geral do Direito do Trabalho. Vol.1.Parte 1. São Paulo: LTr, 2011. p.572.

${ }^{95}$ Nesse sentido, notícia da revista Exame, de 7/11/2013 trazia os "8 pontos para se considerar bem antes de topar ser PJ", não consignando, em momento algum, a ilicitude dessa prática. In <http://exame.abril.com.br/carreira/noticias/proposta-indecorosa> . Acesso em 21/04/2015.
} 
jurídica vão sendo gradativamente redimensionados e substituídos por princípios utilitários de conteúdo econômico. A manipulação da linguagem, por sua vez, como na "passagem" de direitos a privilégios adquiridos, provoca efeitos de eficácia simbólica e identificação imaginária, que dificultam qualquer posicionamento crítico com relação à "nova ordem mundial". Essa manipulação da linguagem evidencia-se, também, no caráter de "naturalidade" de que o neoliberalismo vai revestindo-se enquanto ideologia única. ${ }^{96}$

As decisões envolvendo ponderação, nesse mesmo sentido, legitimam que, em nome da proteção de seu patrimônio, o empregador possa invadir a esfera de proteção da intimidade do trabalhador, uma vez que o interesse maior é a preservação da empresa, pois é ela, em última análise, que "gera emprego e renda e arrecada impostos a serem revertidos para toda a sociedade" ${ }^{17}$. Trata-se, conforme denuncia Ricardo Antunes de um

\begin{abstract}
movimento manipulatório levado ao limite, onde o capital busca o consentimento e a adesão dos trabalhadores, no interior das empresas, para viabilizar um projeto que é aquele desenhado e concebido segundo os fundamentos exclusivos do capital. [...] O operário deve fazer pelo e para o capital, o que aprofunda (ao invés de abrandar) a subordinação do trabalho ao capital. ${ }^{98}$
\end{abstract}

Neste cenário, a jurisprudência acaba por desempenhar um importante papel na desconstrução dos direitos sociais. Marcio Tulio Viana chega mesmo a comparar seus efeitos ao Homem Invisível, personagem de sua infância:

\begin{abstract}
Ao decidir uma causa, mesmo entre João e José, ele [o Tribunal do Trabalho] também pode afetar outros tantos destinos - sem que as pessoas no entanto, o percebam. Em outras palavras, as pessoas o veem, enxergam a sua obra, mas não avaliam muito bem os seus efeitos. E, no entanto, esses efeitos são sempre graves. Eles extrapolam a dimensão de cada processo, seja fortalecendo - em cadeia - todas as normas de proteção, seja transformando-as em seu avesso, ou quando nada subtraindo, pouco a pouco, o que lhes resta de efetividade. ${ }^{99}$
\end{abstract}

\footnotetext{
${ }^{96}$ MARQUES NETO, Agostinho Ramalho. Neoliberalismo: o declínio do direito. In: Direitos humanos e globalização: fundamentos desde a teoria crítica. Rio de Janeiro: Lumen juris, 2004, p.110-124. 97 Julgado TST, RR 977-86.2011.5.05.0019.

98 ANTUNES, Ricardo. Adeus ao trabalho? Ensaio sobre as metamorfoses e a centralidade no mundo do trabalho. 14.ed. São Paulo: Cortez, 2010.p.104.

${ }^{99}$ VIANA, Marcio Tulio. Prefacio. In COUTINHO, Grijalbo Fernandes; MELO FILHO, Hugo Cavalcanti; SOUTO MAIOR, Jorge Luiz; FAVA, Marcos Neves. O mundo do trabalho. Leituras críticas da jurisprudência do TST em defesa do Direito do Trabalho. V.1. São Paulo: LTr, 2009. pp.9-11. p.10.
} 
O que não se percebe, todavia, é que o resultado maléfico não se limita aquele específico caso (não querendo dizer aqui que isso, por si só, já não seria muito), mas essa atitude aparentemente pontual do magistrado, fruto de sua compreensão individual, gera um problema muito maior, de efetividade do próprio Direito do Trabalho.

A doutrina pós-positivista, baseada na máxima da proporcionalidade para a solução dos casos concretos, não oferece qualquer possibilidade de controle acerca do decisionismo de quem sopesa, uma vez que não há como controlar o que se decidiu com base em conceitos extremamente subjetivos como razoabilidade e proporcionalidade.

Mesmo porque, o que legitima a lei de sopesamento como um processo racional é exatamente a fundamentação do que se ponderou como "necessário", "adequado" e "proporcional em sentido estrito", mais uma vez palavras sem qualquer precisão terminológica.

Dessa forma, não há sequer parâmetros para recurso das decisões proferidas, pois se a ponderação procedida se deu com base no juízo de proporcionalidade, restou preenchida a necessidade de fundamentação.

Ademais, num cenário em que a dispensa sem justa causa é a regra, ponderando-se um argumento tão forte como o desemprego, qualquer coisa se torna, então, razoável.

Como bem observado pelo professor Marcus Orione,

Do positivismo fica essencialmente aquilo que há de mais perverso: a naturalização, importada da natureza para as ciências sociais.[...] sob essa premissa positivista, é consolidada a opressão a partir de uma lógica típica dos direitos individuais, importada para os direitos sociais, cuja interpretação passa a se imiscuir com questões econômicas, a se promiscuir com questões morais e, enfim, a se travestir de econômico [...]. Esse exercício perverso, realizado por diversos intérpretes dos direitos sociais, busca esconder-se sob o manto da neutralidade. ${ }^{100}$

Ainda que se diga acerca da possibilidade de decisões em prol do trabalhador, com base no Pós-positivismo, fruto de uma ponderação que, em seu resultado, dê prevalência ao princípio protetor, com ela não podemos concordar.

${ }^{100}$ CORREIA, Marcus Orione Gonçalves. Interpretação dos direitos fundamentais sociais, solidariedade e consciência de classe. In: CANOTILHO, J.J.; CORREIA, M.O.G.; CORREIA, E.P.B (Coord.). Direitos fundamentais sociais. São Paulo: Saraiva, 2010, p. 111-172. p.111. 
Tal fato serviria ao enfraquecimento da própria construção metodológica do Direito do Trabalho, na medida em que estar-se-ia, em última análise, abrindo espaço ao advento de uma ponderação onde, de fato, não há. Seria um recurso extremamente desnecessário e, mais, de todo perigoso, passando a mensagem, ainda que subliminar, que a proteção é algo ponderável, a depender das condições fáticas e jurídicas de determinado caso concreto.

Com efeito, o princípio protetor, base de toda a construção do Direito do Trabalho, por si só, já daria o arcabouço jurídico necessário à solução das demandas apresentadas no presente trabalho, com vistas à preservação da dignidade humana do trabalhador, visando sempre a melhoria de sua condição social.

Nesse contexto, revistas de qualquer sorte restariam plenamente vedadas.

Tais princípios não podem, assim, ser vistos como meros mandamentos de otimização e que, como tais, são passíveis de ser realizados da maior forma possível, a depender de condições fáticas e jurídicas existentes, podendo ceder quando em determinado caso é conferido um peso maior a outro princípio antagônico.

\section{Segundo Grijalbo Coutinho,}

Princípio não tem força de norma. Princípio é norma ou, como declaram alguns doutrinadores, é mais importante do que qualquer norma legislada. É o que dá sustentação ao Direito. Um Direito sem princípios não é ciência no verdadeiro sentido da referida expressão, mas apenas um conjunto de regras posta pela autoridade legislativa ou por alguns autores. ${ }^{101}$

Dentro desse contexto, não há como o Direito Social conviver com princípios que sejam contrapostos aos seus preceitos fundamentais:

[..] seria o mesmo que dizer que o Direito do Trabalho tem por princípio buscar a melhoria da condição social do trabalhador e ao mesmo ser instrumento a serviço da autonomia da vontade. As proposições principiológicas de natureza liberal, postas a serviço do individualismo, para favorecimento da formação do capitalismo estão em contraposição incontornável com os princípios do Direito

\footnotetext{
${ }^{101}$ COUTINHO, Grijalbo Fernandes. O direito do trabalho flexibilizado por FHC e Lula. São Paulo: LTr, 2009, p.11.
} 
Social, que foram desenvolvidos exatamente para a superação desses valores. ${ }^{102}$

Por fim, se é certo que para Robert Alexy a discricionariedade contida no método da ponderação deve ficar limitada a situações em que o sistema jurídico não foi capaz de oferecer a solução em tese, elegendo de antemão um valor ou interesse que deva prevalecer, razão maior não há para sua inaplicabilidade.

$\mathrm{Na}$ seara trabalhista, conforme buscamos demonstrar, os princípios que regem esse direito, historicamente construídos, já representam a ponderação prévia do legislador e, assim, impõe-se uma posição valorativa diante dos conflitos envolvendo capital e trabalho no sentido da melhoria da condição social e da preservação da dignidade do ser humano trabalhador.

102 SOUTO MAIOR, Jorge Luiz. Curso de Direito do Trabalho. Teoria Geral do Direito do Trabalho. Vol.1.Parte 1. São Paulo: LTr, 2011. p.648. 


\title{
CONCLUSÃO
}

\author{
"O que propor, de concreto [para a \\ proteção social do trabalhador no mundo \\ globalizado ] ? No campo da ideologia, \\ desmistificar os mitos, denunciar as \\ contradições, recompor as meias- \\ verdades."
}

- Marcio Tulio Viana

O Direito do Trabalho, como um direito social, ainda enfrenta alguns muitos percalços na tentativa de impor sua racionalidade, enfrentando momentos de avanços e recuos.

Nesse contexto, os ataques a ele provêm das mais diversas frentes, seja de ideologias forjadas no interior da própria doutrina, seja por meio de sua aplicação in concreto, seja por obra do próprio legislador, no intuito de flexibilizar seus preceitos fundamentais.

A resposta a esses ataques, segundo acreditamos, é eficaz quando afirmamos e reafirmamos constantemente o que, de fato, constitui o Direito do Trabalho, qual seu nascedouro, sua principiologia, a que ele se presta. É preciso fortalecer suas bases, para rechaçar os clamores ideológicos por sua reconstrução.

Assim procedendo, desmistificamos os mitos, denunciamos as contradições e recompomos as meias-verdades, a fim de garantir-lhe a sobrevivência o que, em última análise, representa a sobrevivência do próprio modelo capitalista de produção, mas desde que calcado nas bases da justiça social.

É preciso alertar, constantemente, ser este o pacto que firmamos para que retóricas de desconstrução de direitos sociais sequer sejam cogitadas e reste preservado o respeito à racionalidade desenvolvida até o presente momento da história humana. 
Neste cenário, ao serem realizados constantes exercícios de ponderação dos preceitos trabalhistas com preceitos outros de índole meramente liberal, desconsidera-se a própria ponderação histórica feita quando do nascedouro do Direito do Trabalho, no sentido de que a prevalência haveria de ser dada aos preceitos protetivos do trabalhador, por ser este o único meio de se manter o modelo de sociedade do qual ele é originário.

E, conforme buscamos demonstrar no presente trabalho, a prática da ponderação de princípios procedida pelas decisões colacionadas sequer é feita com base na aplicação da teoria de Robert Alexy, o que deixa certo que se trata, em verdade, de mera manifestação da vontade do julgador que, além de desvencilhar-se dos preceitos trabalhistas, assim atua sem qualquer embasamento legal ou teórico.

Sob pena de tal constatação resultar no raciocínio de que o Pós-positivismo de Alexy, caso corretamente aplicado, seria viável à solução dos conflitos envolvendo capital e trabalho, focamo-nos, ainda, em demonstrar sua total inaplicabilidade ao Direito do Trabalho, em virtude de toda a principiologia historicamente construída deste ramo do Direito.

Não há, assim, que se ponderar aquilo que a racionalidade humana estabeleceu como primordial à sua existência e à própria sobrevivência do modelo ora vigente, restando cristalino que deve sempre se priorizar, por respeito à própria história da humanidade, a concretização dos princípios que compõem a autêntica e inafastável função do Direito do Trabalho. 


\section{BIBLIOGRAFIA}

ALEXY, Robert. Teoria dos direitos fundamentais. Tradução de Virgílio Afonso da Silva. São Paulo: Malheiros, 2008.

Conceito e validade do Direito. São Paulo: Martins Fontes, 2011.

Teoria da argumentação jurídica. A teoria do discurso racional como teoria da fundamentação jurídica. Tradução de Zilda Hutchinson Schild Silva. 3.ed. Rio de Janeiro: Forense, 2013.

;BASTIDA, Francisco J.; AMADO, Juán Antonio Garcia; VALDÉS,

Liborio L. Hierro, MORESO, José Juan; PARDO, Celestino; PECES BARBA, Gregorio. Derechos sociales y ponderación. 2.ed. Madri: J.Sán José, 2009.

ALVARENGA, Rúbia Zanotelli de Alvarenga. O direito do trabalho como dimensão dos direitos humanos. São Paulo: Ltr, 2009.

ALVES, Giovanni. Dimensões da precarização do trabalho. Ensaios de Sociologia do Trabalho. Bauru: Canal 6, 2013.

ANTUNES, Ricardo. Adeus ao trabalho? Ensaio sobre as metamorfoses e a centralidade no mundo do trabalho. 14. ed. São Paulo: Cortez, 2010

BARBAGELATA, Héctor-Hugo. O particularismo do direito do trabalho. Tradução de Edilso Alkmim Cunha. São Paulo: LTr, 1996.

BARCELLOS, Ana Paulo de. Ponderação, racionalidade e atividade jurisdicional. São Paulo: Renovar, 2005. 
BARROS, Alice Monteiro de. Proteção à intimidade do empregado. 2.ed. São Paulo: LTr, 2009.

BARROSO, Luís Roberto. O Direito Constitucional e a efetividade de suas normas. Limites e possibilidades da Constituição brasileira. 8.ed. Rio de Janeiro: Renovar, 2006.

BELMONTE, Alexandre Agra. O monitoramento da correspondência eletrônica nas relações de trabalho. São Paulo: LTr, 2004.

BERNARDO, Marcia Hespanhol. Trabalho duro: discurso flexível - uma análise das contradições do toyotismo a partir da vivência dos trabalhadores. São Paulo: Expressão Popular, 2009.

BONAVIDES, Paulo. Curso de direito constitucional. 24a .ed.São Paulo: Malheiros, 2009.

CATHARINO, José Martins. Compêndio de Direito do Trabalho. V.I. 2.ed. São Paulo: Saraiva.

Neoliberalismo e sequela. São Paulo: LTr, 1997.

CESARINO JR., A.F. Direito social brasileiro. 6.ed. São Paulo: Saraiva, 1970.

CORREIA, Marcus Orione Gonçalves. Curso de direito do trabalho - teoria geral do direito do trabalho. Coleção Pedro Vidal Neto. Vol.1. São Paulo: LTr, 2007.

; CANOTILHO, J.J.; CORREIA, Érica Paula Barcha

Correia (coord.). Direitos fundamentais sociais. Saraiva, 2010. 
COUTINHO, Grijalbo Fernandes. O direito do trabalho flexibilizado por FHC e Lula. São Paulo: LTr, 2009.

; MELO FILHO, Hugo Cavalcanti; SOUTO MAIOR, Jorge Luiz; FAVA, Marcos Neves (coord.). O mundo do trabalho - leituras críticas da jurisprudência do TST: em defesa do direito do trabalho. vol. 1. São Paulo: LTr, 2009.

DAL ROSSO, Sadi. Mais trabalho! A intensificação do labor na sociedade contemporânea. São Paulo: Boitempo, 2008.

DELGADO, Mauricio Godinho. Curso de Direito do Trabalho. 8.ed. São Paulo: LTr, 2009.

DWORKIN, Ronald. Levando os direitos a sério. Tradução de Nelson Boeira. São Paulo: Martins Fontes, 2007.

GEMIGNANI, Tereza Aparecida Asta. Direitos fundamentais e sua aplicação no mundo do trabalho. Questões controversas. São Pau lo: Ltr, 2010.

GOMES, Orlando. Estudos de direito do trabalho. $3^{\text {a }}$ ed. São Paulo: LTr, 1979.

GRAU, Eros Roberto; GUERRA FILHO, Santiago. Direito Constitucional. Estudos em homenagem a Paulo Bonavides. São Paulo: Malheiros, 2003.

HERRERA FLORES, Joaquín. Los derechos humanos como productos culturales. Crítica del humanismo abstracto. Madri: Los libros de la Catarata, 2005. 
LEITE, George Salomão (org.). Dos princípios constitucionais. Considerações em torno das normas principiológicas da Constituição. São Paulo: Malheiros, 2003.

OLIVEIRA, Eurenice. Toyotismo no Brasil. São Paulo: Expressão popular, 2004.

MARCELINO, Paula Regina Pereira. A logística da precarização: terceirização do trabalho na Honda do Brasil. São Paulo: Expressão Popular, 2004.

MORAES, Evaristo de. Apontamentos de direito operário. 4. ed. São Paulo: LTr, 1998.

MORAES FILHO, Evaristo. Introdução ao Direito do Trabalho. 4.ed. São Paulo: LTr, 1986.

MOTA, Marcel. Pós positivismo e restrição de direitos fundamentais. Fortaleza: Omni, 2006.

MOURAL, Leunice S. Moreira de (org.). O novo constitucionalismo na era póspositivista: homenagem a Paulo Bonavides. São Paulo: Saraiva, 2009.

NUNES, António José Avelãs. Neoliberalismo e direitos humanos. Rio de Janeiro: Renovar, 2003.

OLSEN, Ana Carolina Lopes.A eficácia dos direitos fundamentais sociais frente à reserva do possível. 2006. 390 f. Dissertação (Mestrado em Direito) - Setor de Ciências Jurídicas, Universidade Federal do Paraná, Curitiba, 2006. 
PELÁEZ, Francisco J. Contreras. Derechos sociales: teoría e ideología. Madri: Tecnos, 1994.

PINTO, Geraldo Augusto. A organização do trabalho no século 20. Taylorismo, Fordismo e Toyotismo. São Paulo: Expressão Popular, 2007.

REIS, Daniela Murada. O princípio da vedação do retrocesso no direito do trabalho. São Paulo: Ltr, 2010.

Revista Latino-americana de Estudos Constitucionais, v.1., 2003.

RODRIGUEZ, Américo Plá. Princípios do direito do trabalho. $3^{\text {a }}$.ed. São Paulo: Ltr, 2002.

RÚBIO, David Sanchez; FLORES, Joaquín Herrera; CARVALHO, Salo de (Org.). Direitos humanos e globalização: fundamentos e possibilidades desde a teoria crítica. Rio de Janeiro: Lumen juris, 2004.

SARLET, Ingo Wolfgang. A eficácia dos direitos fundamentais. 9 . $^{\mathrm{a}}$. Porto Alegre: Livraria do Advogado, 2008.

SILVA, Virgílio Afonso da. Direitos fundamentais - conteúdo essencial, restrições e eficácia.São Paulo: Malheiros, 2009.

(org.). Interpretação constitucional. São Paulo: Malheiros,

2010.

. Princípios e regras: mitos e equívocos acerca de uma distinção. Revista Latino-americana de Estudos Constitucionais, v.1., 2003. 
SARMENTO, Daniel. Direitos fundamentais e relações privadas. $2^{\mathrm{a}}$ ed. Rio de Janeiro: Lumen Juris, 2006.

SOUTO MAIOR, Jorge Luiz. O direito do trabalho como instrumento de justiça social. São Paulo: LTr, 2000.

; SILVA, Alessandro da; FELIPPE, Kenarik Boujikian; SEMER, Marcelo (coord.). Direitos humanos: essência do direito do trabalho. São Paulo: LTr, 2007. Curso de Direito do Trabalho. A relação de emprego.

V.II., São Paulo: LTr, 2008.

Curso de Direito do Trabalho. Teoria Geral do Direito do Trabalho. V.I. São Paulo: LTr, 2011.

TORRES, Ricardo Lobo (org.). Legitimação dos direitos humanos. 2.ed. Rio de Janeiro: Renovar, 2007.

TRINDADE, José Damião de Lima. Os direitos humanos na perspectiva de Marx e Engels. Emancipação política e emancipação humana. São Paulo: Alfa-Omega, 2011. 